\title{
Osmanlı Taşrasında Bir Kamu Görevlisi, Ali Saib Bey ve İşkodra Vilayetine Dair Layihası
}

\section{A Public Official in the Ottoman Province, Ali Saib Bey and His Annex on Shkoder Province}

\author{
H. Baha ÖZTUNÇ ${ }^{1}$ (])
}

'Dr. Öğr. Üyesi, Tokat Gaziosmanpaşa Üniversitesi Fen-Edebiyat Fakültesi, Tarih Bölümü, Tokat, Türkiye

\section{ORCID: H.B.Ö. 0000-0002-6995-633X}

Sorumlu yazar/Corresponding author: H. Baha Öztunç,

Tokat Gaziosmanpaşa Üniversitesi Fen-Edebiyat Fakültesi, Tarih Bölümü, Tokat, Türkiye

E-posta/E-mail:

bahaoztunc@gmail.com

Başvuru/Submitted: 05.05.2020 Revizyon Talebi/Revision Requested: 18.05.2020

Son Revizyon/Last Revision Received: 21.05.2020

Kabul/Accepted: 21.05.2020

Atıf/Citation: Oztunc, H. B. (2020). Osmanlı Taşrasında Bir Kamu Görevlisi, Ali Saib Bey ve İşkodra Vilayetine Dair Layihası. Yakın Dönem Türkiye Araştırmaları-Recent Period Turkish Studies, 37: 51-94.

https://doi.org/10.26650/YTA2020-003

\begin{abstract}
ÖZ
Osmanlı Devleti'nin bürokrasi kadrosu, 19. yüzyılda ve özellikle Gülhâne Hatt-1 Hümayunu akabinde oluşturulan yeni kurumlarla oldukça genişlemiş ve ortaya çıkan personel ihtiyacı gerek merkez gerekse taşrada bu ihtiyaca cevap verecek kadrolaşma çalışmalarıyla giderilmeye çalışılmıştır. Bu çalışmada öncelikle son dönem Osmanlı bürokratlarından olan Ali Saib Bey’in 15 yaşında Malatya sancağı tahrirat kaleminde başlayan memuriyet hayatı ortaya konulacaktır. Daha sonra, Ali Saib Bey'in 29 Ekim 1911 tarihinde el yazması olarak kaleme aldığı ve tarafımca bir müzayededen temin edilmiş olup Cumhurbaşkanlığı Devlet Arşivi'nde tespit edilemeyen "İşkodra Vilâyeti'nde İcrâsı Tasavvur Buyurulan Tedâbir-i Islâhiyeye Dâ'ir Ba'zı Ma'lûmât ve Mütâla‘ât-1 Fâhirâne” başlıklı raporu değerlendirilecektir. Böylelikle hem Osmanlı taşrasında değişik hizmetlerde bulunan bir bürokratın memuriyet serüveni ortaya çıkartılacak hem de İșkodra vali vekilliği görevinde de bulunan Ali Saib Bey’in bu vilayetle ilgili problemlerin tespit ve giderilmesi hakkındaki önerileri incelenecektir. Çalışmanın ana kaynağını söz konusu layiha ve Cumhurbaşkanlığı Devlet Arşivi'nden Ali Saib Bey’le ilgili tespit edilen belgeler oluşturmakla beraber konuyla ilgili literatürde bulunan araştırma eserlerden de faydalanılacaktır.

Anahtar Kelimeler: Ali Saib Bey, İșkodra, Malisör, Islahat, Layiha
\end{abstract}

\section{ABSTRACT}

The bureaucracy of the Ottoman State expanded considerably upon the foundation of new institutions in the $19^{\text {th }}$ century following the Rescript of Gülhane, and the emerging needs for staff were met with staffing efforts both in the center and in the provinces. The civil service life of Ali Saib Bey, one of the last Ottoman bureaucrats, who started his mission as correspondence officer at the age of 15 in Malatya sanjak, will be revealed in this study. And later, his report the “İşkodra Vilâyeti’nde İcrâsı Tasavvur Buyurulan Tedâbir-i 
Islâhiyeye Dâ'ir Ba'zı Ma'lûmât ve Mütâla'ât-1 Fâhirâne”, which was written by Ali Saib Bey as a manuscript on October 29, 1911 and obtained from an auction by the researcher, and was unavailable in the Presidential State Archive, will be evaluated. So, both the bureaucratic process of a bureaucrat who served in different services in the Ottoman provinces and the detection and elimination recommendations of the problems related to this province by Ali Saib Bey, who also served as the deputy governor of Shkoder, will be examined. The main source of the study consists of this relevant annex and documents found about Ali Saib Bey in the Presidential State Archive, and the previous research in the literature on this subject will also be utilized.

Keywords: Ali Saib Bey, Shkodra, Malisör, The Reform, Report

\section{Extended Abstract}

This study's purpose is to provide information about Ali Saib Bey, who was in service in various provincial offices in the Ottoman State for many years and was the author of the annex which constitutes the main subject of the article. On the other hand, another purpose of the study was to determine the issues and recommendations stated in the annex and reveal whether these recommendations were realized through archive documents.

The civil service life of a public servant who served in the Ottoman provinces for many years will be examined in this study. Many issues such as his duties, assignments, and rewards taken by this officer in the provinces will be revealed in this section. In addition, the presentation of the annex that Ali Saib Bey wrote was also important in terms of showing what problems he had in Shkoder, which would come out shortly after the Ottoman Empire, and what recommendations were put forward to overcome these problems. The question of whether these recommendations were taken into consideration were examined through documents in the Presidential Ottoman Archives. It is thought that the findings obtained within the framework of this annex, which reveal the central-provincial relations and have not been studied before, will contribute to the history of this territory.

The first step in the method followed during the study was to collect data about the civil service life of Ali Saib Efendi, the owner of the annex. Later, it was evaluated in accordance with the original partition by making content analysis of the annex. And then, the documents obtained as a result of the review carried out in the Presidential Ottoman Archive on the subjects mentioned in the annex were compared. The studies conducted on the related territory were utilized for the data related to Shkoder. In this respect, the main source of the study was the annex of Ali Saib Bey and the documents obtained in the Presidential Ottoman Archive. 
Ali Saib Bey, the son of a soldier father, started his career as a correspondence clerk in Malatya sanjak at a very young age and served in many parts of the country. Ali Saib Efendi, who came to Shkoder with his position as a provincial letter officer on February 1,1909 , also served as deputy governor of Shkoder during this duty. Ali Saib Bey, who briefly summarized his civil service life in this way, wrote an annex dated October 29, 1911 that formed the subject of this study. Initially, he transferred the geographical borders and population information of the province. In the section titled political and social situation and urgent needs of Shkoder, he emphasized the issue of Malesori, for which he was also assigned. One of the important determinations he made was that it was the most important problem of the people in this place to be in ignorance and misery. Also, the efforts of Austria and Italy to influence here are another issue that was mentioned in the annex. It was understood from the statements of Ali Saib Bey that they took the hearts of the people through the great investments they made in the region and that even some of the Muslims in the Malesori region left their religions for this reason. It was a remarkable determination that the people in Malesori and Shkoder took refuge in the patronage of Montenegro, which was their enemy. An important determination in this section was that the Ottoman ambassador in Çetine was acting as if he were supporting Montenegro. After this section, Ali Saib Bey gave information about the law that he defined as "not fit for civilization and humanity" under the title of Dukakin Law. The next title was education. In the annex stating that Shkoder was not at the desired level in education, it was worth noting that many of the teachers with insufficient salaries did not know Ottoman Turkish. The most important recommendation in this section was that an industrial school should be opened there. Under the title of Public Works, it mentioned that the situation of the roads was very bad and that it was necessary to do something as soon as possible. Another point mentioned in this section was that foreign engineers and conductors did not want to go to their places owing to various excuses. Under the public order title, it determined that the coast of Shkoder Lake, up to Boyana and Drac, was open to smuggling and that it was a necessity to set up observation towers in suitable places on the coast, and he emphasized the necessity of installing a telephone line between them. In the title on agriculture, he stated that agriculture was done in the old way due to the financial deficiencies of the people. Therefore, he emphasized that it was necessary to increase the capital of the agricultural bank there and to open the branch of the bank in some towns. Opening a sample field on which Ali Saib Bey was standing was one of the recommendations put into practice. Another important determination in this section is that Shkoder was very rich in terms of forest but it was not utilized properly. Under the heading of civil service, some significant opinions were given about administrative arrangements 
that needed to be made by giving the current administrative division of Shkoder. The most noteworthy of these was the proposal to assign the Muslims or Christians in Shkoder, who could speak the local language, as the head of the district. Under the heading of officers to be assigned to Shkoder, it was requested that the unqualified ones be taken from there and replaced by experienced officers, and that the salaries and liabilities of the officers who would work there should be made regularly. The most striking point in the headline of politics to be implemented in Shkoder was that almost all of the people across the province had an attitude towards the government and that the people of the territory should not behave violently as a result of their nature, but it would not also result in being too soft. The only thing to do was to meet in the middle. It was another recommendation that mobile doctors should be assigned there and that these doctors should constantly treat people who were sick in the villages and mountains and make the state propaganda. Finally, it was recommended that the loyalty of the people to the state should be provided through the Muslim and Christian opinion leaders and that the financial support should be provided to poor people as much as possible.

The annex written by an officer who worked in different parts of the Ottoman Empire as the correspondence clerk of Shkoder was an important document in order to understand center-provincial relations. There were some recommendations by Ali Saib Bey that were realized as well as those that could not be realized due to financial difficulties. As a result, thinking about how to manage Shkoder better and how to handle the current problems, Ali Saib Bey explained these issues in detail. However, neither this annex nor the efforts of the Ottoman State yielded any results, and Shkoder came out of the hands of the Ottomans as a result of the Balkan Wars. 


\section{Giriş}

Osmanlı Devleti'nin kuruluş dönemindeki teşkilatlanmada seyfiye ve ilmiye sınıflarıyla birlikte, bürokratik sınıfı işaret eden kalemiye sınıfı bulunmaktaydı. XIX. yüzyılla birlikte "seyfiye" terimi kullanılmamaya başlandığ 1 gibi, "kalemiye" ifadesi de yerini "mülkiye" terimine bırakıyordu1. Özellikle Gülhâne Hatt-1 Hümâyûnu akabinde genişleyen bürokrasi, kamudaki insan kaynağı ihtiyacını da artırmış ve gerek merkezde gerekse taşrada, sayıları sürekli artan memur kadrosu görülmeye başlamıştı².

Çalışmanın merkezindeki bürokrat olan Ali Saib Bey de bürokrasi basamaklarını tırmanarak vali vekilliği görevine kadar ilerlemiş bir devlet memurudur. Makalenin asıl nüvesini oluşturan raporu Osmanlı Devleti'ndeki layiha geleneği içinde değerlendirmek yerinde olacaktır. Arapça kökenli olan "lâyiha" kelimesinin "düşünülen bir şeyin yazı hâline getirilmesi" anlamına geldiği görülmektedir. Osmanlı Devleti, layihayı rapor ve taslak olarak iki belge türünde kullanmaktadır. Islahat layihaları, bir memuriyet veya teftiş sonrasında tespit edilen hususların kaleme alındığı layihalar, bir mesele hakkında görüş bildiren layihalar ve esbâb-1 mucibe layihaları rapor mahiyetindeki layihalar grubuna girerken; bir de taslak mahiyetindeki layihalar vardır³. Buradan hareketle çalışmanın konusu olan layihayı, rapor mahiyetindeki layihalar içinde bulunan bir memuriyet veya teftiş sonrasında tespit edilen hususların kaleme alındığı layihalar içinde kabul etmek yerinde olacaktır.

\section{Ali Saib Bey ve Memuriyet Hayatı}

Ali Saib Bey’in gerek kim olduğu gerekse görev aldığı memuriyetlerle ilgili Türkiye Cumhuriyeti Cumhurbaşkanlığı Devlet Arşivleri Başkanlığı Osmanlı Arşivi’nde yapılan tarama neticesinde hem sicil dosyasına hem de çeşitli atama kararlarıyla ilgili belgelere ulaşıldı. Sicil dosyasındaki bilgilere bakılacak olursa Ali Saib Bey, Dördüncü Ordu Atîk Süvari İkinci Alayı miralayı ve Malatya’da Sultan Suyu Çiftliği nazırlığı görevlerinde bulunmuş olan müteveffa Mehmed Rahmi Bey'in oğludur. 1864 yılında Erzincan'da doğan Ali Saib Bey, sırasıyla sıbyan mektebi ve Malatya Rüştiyesi'ni bitirdi. Arapça ve

1 Mehmet İpşirli, "Kalemiye", Türkiye Diyanet Vakfi İslâm Ansiklopedisi (DİA), C. 24, Diyanet Vakfı Yayınları, İstanbul, 2001, s. 248.

2 Osmanlı Devleti'nde bürokrasinin şekillenmesiyle ilgili yapılan çalışmalardan bazıları: Carter V. Findley, Osmanlı Imparatorluğu'nda Bürokratik Reform Babıâli, 1789-1922, çev. Ercan Ertürk, İstanbul, Tarih Vakfi Yurt Yayınları, 2014; Ali Akyıldı, Tanzimat Dönemi Osmanlı Merkez Teşkilâtında Reform (1836-1856), İstanbul, Eren Yayınları, 1993; İlber Ortaylı, Tanzimat Devrinde Osmanlı Mahallî Iddareleri (1840-1880), Ankara, Türk Tarih Kurumu Yayınlar1, 2000; Mehmet Seyitdanlığlu, Tanzimat Devrinde Meclis-i Vâlâ (1838-1868), Ankara, Türk Tarih Kurumu Yayınları, 1999; Mehmet Güneş, Osmanlı Devleti'nde Kaymakamlı (1842-1871), İstanbul, Kitabevi Yayınları, 2014.

3 Mübahat S. Kütükoğlu, Osmanl Belgelerinin Dili (Diplomatik), İstanbul, Kubbealtı Neşriyat, 1998, s. 335-337; Mübahat S. Kütükoğlu, "Lâyiha”, DİA, C. 27, Diyanet Vakfı Yayınları, Ankara, 2003, s. 116. 
Farsça bilgisi az, Türkçe okur-yazar ve telgraf kullanımına vakıf olup, yapılan imtihan neticesinde 21 Ocak 1886 tarihinde ikinci sınıf tahrirat müdürlüğüne hak kazanır.

Ali Saib Bey’in memuriyet hayatı henüz 15 yaşındayken Malatya sancağı tahrirat kalemine girmesiyle başlar. Burada maaşsız memuriyete devam eden Ali Saib Bey, 13 Şubat 1881 tarihinden 5 Ocak 1883 tarihine kadar 100 kuruş maaşla Malatya livası muhasebe kalemi "mesâlih-i câriye" refakatinde bulunur. Aynı yılın nisan ve mayıs aylarında 1.500 kuruş ücretle görevine ilaveten Malatya ağnam müfettişliği görevinde bulunur. 6 Ocak 1883 tarihinde 275 kuruş maaşla Malatya belediye dairesi kâtipliği görevine getirilen Ali Saib Bey, 26 Aralık 1884 tarihinde izinli olarak İstanbul'a gelerek bir süre Bâb-1 Âli tercüme kalemine devam eder. 15 Mayıs 1886 tarihinde 800 kuruş maaşla Sivas vilayeti merkez mutasarrıflığı tahrirat müdürlüğüne tayin edilir ama ilgili müdürlüğün lağvıyla beraber 30 Temmuz 1886 tarihinde aynı maaşla Sivas vilayeti idare meclisi kitabetine ve 27 Eylül 1886'da ise 1.200 kuruş maaşla Malatya tahrirat müdürlüğüne nakledilir. Bu görevini yürütürken ilave memuriyet olarak 13 Haziran 1888 tarihinden itibaren 41 gün süreyle ve 250 kuruş zamlı maaşla Hısnımansur kaymakam vekilliğinde bulunur. 27 Ekim 1888 tarihindeyse Hakkâri sancağı tahrirat müdürlüğü görevine getirilen Ali Saib Bey ilave memuriyetle 15 Mart-5 Nisan 1889 tarihleri arasında gönüllü olarak, 30 Mayıs-12 Haziran 1889 tarihleri arasında da 1.300 kuruş maaşla, 27 Eylül-5 Kasım 1889’a ve 20 Mayıs-15 Temmuz 1890 tarihleri arasında yine gönüllü olarak Hakkâri mutasarrıf vekilliği görevini yerine getirir. Aynı dönemde Amâdiye kazasının R.1307 (1891-92) senesi aşarının ihalesiyle görevlendirilerek 50 gün için 60 kuruş yevmiyeyle çalışır. Gerek asıl memuriyeti gerekse yürüttüğü mutasarrıf vekilliği görevlerini başarıyla yaptığı Hakkâri mutasarrıflığı tarafından yazılan mülâhazada ifade edilen Ali Saib Bey’e, bu başarılarından dolayı 1 Ekim 1893 tarihinde "rütbe-i râbi ' $a$ " verilir". 20 Mart 1894 tarihinde 1.200 kuruş maaşla Lazkiye sancağı tahrirat müdürlüğüne atanır. 26 Mart 1895-11 Mayıs 1895 tarihleri arasında bu defa Ceble kazası kaymakam vekâleti görevini yürütür. Ali Saib Bey, 13 Şubat 1896 tarihinde kendisinin talebi üzerine Beyrut vilayeti evrak müdürlüğüne nakledilir. 22 Eylül 1896 tarihinde eski memuriyeti olan Lazkiye tahrirat müdürlüğüne getirilir. 2 Eylül 1897 tarihinde bir terfi daha alarak "rütbe-i sâlise" ile taltif edilir. Ceble ve Merkub kazalarının 1897/98 senesi aşarının toplanmasına görevlendirilen Ali Saib Bey, eski bedellerinin 43.677 kuruş fazlasını toplamayı başarır ve 61 günlük bu görevi nedeniyle 3.822 kuruş alır. 2 Ocak-12 Mart 1898 arası Lazkiye sancağı mutasarrıf vekâletini yürütür. 4 Eylül 1898 tarihinde bu defa "rütbe-i sâniye" ile taltif edilen Ali Saib Bey ilk olarak 19 Nisan

4 Devlet memurlarına verilen rütbe ve nişanlarla ilgili bkz. Ali Akyıldız, Tanzimat Dönemi Osmanlı Merkez Teşkilatında Reform (1836-1856), İstanbul, Eren Yayınları, 1993, s. 42-47. 
1898-7 Ocak 1899 arasında 1.800 kuruş maaşla ve ikinci olarak 27 Aralık 1898-13 Mart 1899 arasında yine aynı maaşla Nablus sancağı mutasarrıf vekilliği görevini yürütür. 16 Eylül 1899 tarihinde 1.800 kuruş maaşla Beyrut vilayeti idare meclisi başkatipliğine tayin edilir. 16 Nisan 1900 tarihinde bu defa 1.700 kuruş maaşla Basra vilayeti mektupçuluğuna tayin olunur. 15 Haziran 1900-13 Mart 1902 tarihleri arasında yaptığı mektupçuluk görevindeyken rahatsızlığı nedeniyle hava değişimi isteyen Ali Saib Bey’in doktor raporu da aynı tespitte bulununca, kendisi Beyrut veya İstanbul'a tayinini ister; ancak Dâhiliye Nezâreti buna izin vermeyince istifa eder ${ }^{5}$. Bu arada vazifesini iyi yaptığ için kendisine 13 Aralık 1899 tarihinde “4. Rütbeden Nişân-ı Âlî-i Osmânî” verilir6.

İstifa eden Ali Saib Bey’e, 28 Eylül 1902 tarihinde 675 kuruş emekli maaşı bağlanır. Uzun süre emekli kalmayan Ali Saib Bey’in 14 Mart 1904 tarihinde 1.200 kuruş maaşla Dâhiliye Nezâreti mektubi kalemi mümeyyizliğine atandığı görülmektedir. Bu görevi esnasında 24 Nisan 1904 tarihinde "rütbe-i sınıf mütemâyizi" olarak terfii edilir. 5 Aralık 1905 tarihinde ilgili müdürlüğün muavinliğine getirilir ${ }^{7} .12$ Aralık 1906 tarihinde kendisine "3. rütbeden Mecîdi Nişanı” verilir.

Ali Saib Bey’in memuriyet hayatının Rumeli coğrafyasıyla kesişmesi, 1 Şubat 1909 tarihinde 2.700 kuruş maaşla İşkodra vilayeti mektupçuluğuna tayin edilmesiyle olur ${ }^{8}$. Görevi esnasında 3 Eylül-18 Ekim 1910 ve 18 Nisan-1 Mayıs 1911 tarihleri arasında İşkodra vali vekilliği yapar. 13 Eylül 1911 tarihinde izinli olarak İstanbul'a gelir. İşkodra vilayeti idare meclisi, görev yaptığı süre zarfında iyi bir yönetim gösterdiğine dair 22 Eylül 1911 tarihinde bir mazbata kaleme alır. 6 Ocak 1912 tarihinde Sinop vilayeti tahrirat müdürlüğüne nakledildiği kaydedilen Ali Saib Bey, 4 Şubat 1912 tarihinde 3.000 kuruş maaşla Hicaz vilayeti tahrirat müdürlüğüne tayin olunur? 9

Ali Saib Bey’in İşkodra vali vekilliği görevine getiriliş süreci kısaca şu şekilde gelişmiştir: Valilik görevi verilmek istenen Şevket Turgut Paşa, Dâhiliye Nezâreti’ne

5 Ali Saib Bey'in istifa nedenini dönemin Basra valisi ve kumandanı olan Mustafa Nuri; "buranın âb ve havastyla imtizâc edememesinden" ifadesiyle açıklamakta, Ali Saib Bey de konuyla ilgili Dâhiliye Nezâreti’ne gönderdiği uzun telgrafında yirmi seneden beri devlet memurluğu görevini başarıyla ifa ettiği, yer değiştirme ve hava değişimi için dört ay izin taleplerinin geri çevrilerek kendisine istifadan başka bir seçenek kalmadığını belirtmektedir. Bkz. Türkiye Cumhuriyeti Cumhurbaşkanlı̆̆ Devlet Arşivleri Başkanlı̆̆ Osmanlı Arşivi (BOA), Dahiliye Mektubi (DH.MKT), 2600/28, leff 1-2, 4 Mart 1318 (17 Mart 1902)-1 Zilhicce 1319 (11 Mart 1902).

6 Bu taltif dönemin Basra Valisi tarafından mektupçuluk görevini iyi yaptığı için 6 Aralık 1900 tarihinde teklif edilmişti. Bkz. BOA, Dahiliye Şifre (DH.ŞFR), 254/41, leff 1-2, 23 Teşrîn-i Sânî 1316 (6 Aralık 1900).

7 BOA, Dahiliye Defterler (DH SAID.d), 55/166, s. 329-330.

8 Ali Saib Bey'in bu göreve atanmasıyla ilgili irade 1 Şubat 1909 tarihinde çıkmıştır. Bkz. BOA, Irade Dahiliye (İ.DH), 1473/32, leff 2, 19 Kânûn-1 Sânî 1324 (01 Şubat 1909); BOA, Bâbiâli Evrak Odası (BEO), 3484/261269, 22 Kânûn-1 Sânî 1324 (4 Şubat 1909).

BOA, DH SAID.d, 150/78, s. 153 . 
gönderdiği 19 Nisan 1911 tarihli yazıda, askerî işlerle çok meşgul olduğundan görevi kabul edemeyeceğini ve yerine tahrirat müdürü Ali Saib Bey’in atanmasının uygun olacağını ifade eder. Aynı gün Ali Saib Bey de Dâhiliye Nezâreti'ne durumu bildirerek kendisine görev verilmeden işlem yapamayacağını, resmî işlerin aksamaması için ne yapılması gerektiğini sorar. Dâhiliye Nezâreti, konuyla ilgili Şevket Turgut Paşa'ya gönderdiği cevapta, Ali Saib Bey'in vali vekili adına imza atabileceğini ifade eder ${ }^{10}$. Ali Saib Bey de bu yazı üzerine 23 Nisan 1911 tarihinde, "Şevket Turgut Paşa vesâtatıyla telakkî ettiğim emr-i nezâretpenâhîlerine imtisâlen ve her dürlü müşkilâta rağmen umûr-l vilâyeti bi'l-vekâle îfâya başladiğım ma 'rûzdur" ifadeleriyle göreve başladığını bildirir' ${ }^{11}$. Aslında Dâhiliye Nezâreti vali vekilliği görevini Şevket Turgut Paşa’ya vermiş ve Ali Saib Bey’i vali vekili adına imza atmakla yetkilendirmişti. Bununla ilgili olarak Şevket Turgut Paşa’ya Dâhiliye Nezâreti’nden 6 Mayıs 1911 tarihli gönderilen yazıda, vilayetten gelen telgrafların tahrirat müdürü tarafından vali vekili sıfatıyla imzalandığı, oysaki vali vekaletinin kendilerinde olduğunu ve eğer Ali Saib Bey’e itimatları varsa ancak vali vekili adına “tahrirat müdürü" ifadesini kullanarak imza atabileceği ifade edilmektedir ${ }^{12}$. Bundan iki gün sonra ise vilayet vekâletinin tahrirat müdürü Ali Saib Bey’e tevdii uygun görülmüştür denilerek vali vekilliği görevinin kabul edildiği bilgisi verilmektedir ${ }^{13}$.

Ali Saib Bey’in tahrirat müdürlüğü ve vali vekilliği görevleri, İşkodra vilayeti ile ilgili tecrübelerini de arttırdı. Kendisinin Malisör meselesinde gösterdiği yararlılık, "İ̧̧kodra Heyet-i Tahkîkiyesi” başkanı Suriye Valisi Müşir Mehmed Kâzım Paşa'nın kendisini bu görevde yanına almak istemesine neden oldu. Mehmed Kâzım Paşa, kartvizitinin arkasına konuyla ilgili şu notu düşer: "İşkodra'da hizmet-i kitâbet husûsunda müstahdem olub Malisör mes'elesinde pek çok yararlı̆̆ını gördüğ̈̈̈m hâmil-i kart levâzımât-ı umûmiye dâ'iresi 6. şûbesine me'mûr ve tabur kâtibi Ali Sâ'ib Efendi'nin buradaki me'mûriyeti yine uhdesinde kalmak ve avdetimde berâber getirmek üzere muvakkaten refâkat-i âcizîye ta 'yîni husûsunun savb-ı sadâretpenâhîlerinin harbiye nezâretine bâ-tezkire teblĭg buyurulmasını istirhâm ederim efendim”. Mehmed Kâzım Paşa'nın ilgili kartviziti aşağıda görülmektedir ${ }^{14}$.

10 BOA, Dahiliye Mütenevvia (DH.MTV), 6-1/81, leff 1, 2, 3, 6 Nisan 1327 (19 Nisan 1911).

11 Aynı belge, leff 4, 9 Nisan 1327 (22 Nisan 1911).

12 BOA, DH.MTV, 6-2/25, leff 1, 23 Nisan 1327 (6 Mayis 1911).

13 Aynı belge, leff 2, 25 Nisan 1327 (8 Mayıs 1911).

$14 B O A, B E O, 4088 / 306553$, leff 4. 

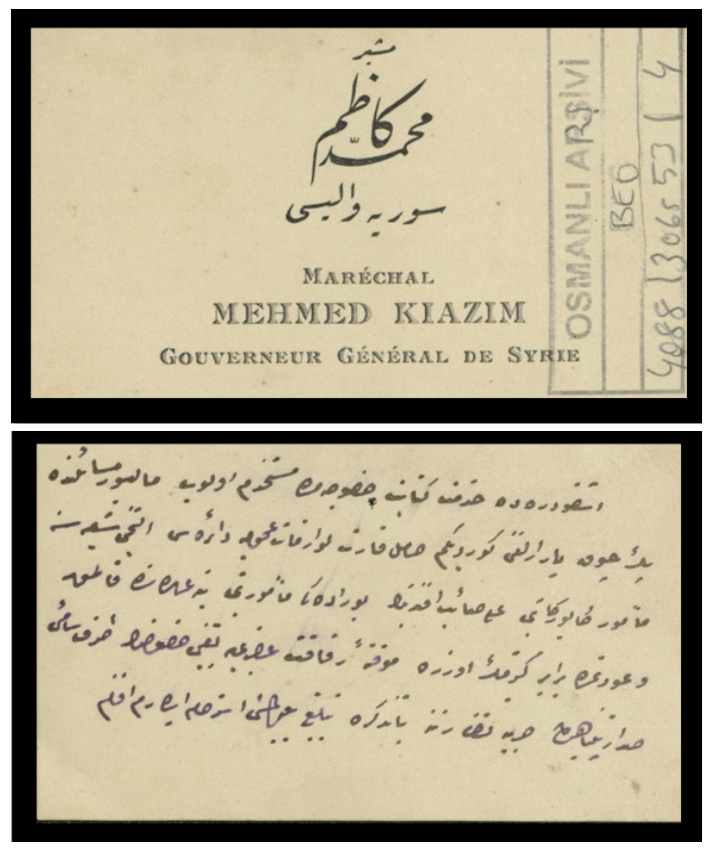

Görüntü 1: Mehmed Kâzım Paşa’nın kartviziti

Paşa'nın bu talebi üzerine, Ali Saib Bey'in yapmakta olduğu "levâzımât-ı umûmiye dâ'iresi altıncı şûbe tabur kâtibliğì" görevi uhdesinde kalmak şartıyla, Mehmed Kâzım Paşa'nın refakatinde görevlendirilmesinin kabulü ve gereğinin bir an evvel yapılması Sadaret tarafından Harbiye Nezâreti'nden istenmişti ${ }^{15}$. Harbiye Nazırı adına müsteşar vekili üç gün sonra Sadaret'e gönderdiği bilgi yazısında ilgili görevlendirmenin yapıld1ğını haber vermişti ${ }^{16}$. Ali Saib Bey, söz konusu göreve gitmek için harcırah talep etmiş ve İstanbul'dan hareketinde deniz yolu ile ulaşımın sağlanacağı hesabıyla Harbiye Nezâreti tarafindan 750 kuruşluk harcırah verilmişti. Ancak Ali Saib Bey, süregelen Balkan Savaşları dolayısıyla deniz yolundan gidememiş ve görev yerine kara yoluyla gidip geri dönmüştü. Bu nedenle harcırahının buna göre yeniden düzenlenmesini talep etmekteydi ki çıkan karar; Avrupa'ya kara yoluyla giden memurlara verilen harcırah kadar para verilmesi şeklinde olmuştu ${ }^{17}$

15 Aynı Belge, leff 1, 13 Eylül 1328 (26 Eylül 1912).

16 Aynı Belge, leff 2, 16 Eylül 1328 (29 Eylül 1912).

17 BOA, Meclis-i Vâlâ (MV), 173/58, 24 Kânûn-1 Sânî 1328 (4 Şubat 1913). 


\section{Ali Saib Bey'in Layihası}

Devlet memurluğu süresi boyunca İşkodra'daki faaliyetleri ile dikkat çeken Ali Saib Bey'in, vilayetin genel problemleri üzerine de tespitleri ve çözüm önerileri vard1. Bunları Isskodra Vilâyeti'nde Ícrâsı Tasavvur Buyurulan Tedâbir-i Islâhiyeye Dâ 'ir Ba 'zı Ma 'lûmât ve Mütâla 'ât-ı Fâhirâne başlıklı layihasında ortaya koydu'18. El yazısıyla kaleme alınan 20 sayfalık layihada; Malisya ve Malisörler, Işsodra'nın Ahvâl-i Siyâsiye ve İctimâ 'iyesi ve İhtiyâcât-ı Âcilesi, Dukakin Kânûnu, Ma ârif, Nâfi 'a, Zirâ' 'at, Teşkîlât-l Mülkiyesi, İşkodra'ya Ta'yîn Olunacak Me’mûrînin Ahvâli ve Onlar Hakkında Hükûmetce Yapılması Lâzım Gelen Mu'âmele, İşkodra'ca Ta 'kîb Olunacak Siyâset, Hülâsâ, başlıkları bulunmaktadır. Layihanın sonunda "İşkodra Tahrîrat Müdürü Bende Ali Sâ'ib” imzası ve 16 Teşrîn-i Evvel 1327 (29 Ekim 1911) tarihi bulunmaktadır ${ }^{19}$. Ali Saib Bey, 25 Şubat 1909 tarihinden itibaren İşkodra vilayeti tahrirat müdürlüğüne atandığı gibi 3 Eylül -18 Ekim 1910 ve 5 Nisan 1327/18 Nisan -17 Mayıs 1911 tarihleri arasında vali vekilliği görevini de ifa etmişti ${ }^{20}$. 6 Ocak 1912 tarihinde Sinop'a atandığ 1 göz önüne alındığında, layihayı İşkodra tahrirat müdürlüğü görevini yaparken yazdığı kuvvetle muhtemeldir. Layihanın 18-20. sayfalarında Hülâsa başlı̆̆ıyla Ali Saib Bey’in metinde ayrıntılı şekilde verdiği öneriler, maddeler halinde sıralanmıştır. Bu nedenle, Hülâsa başlığı altındaki verilere çalışmada ayrıca yer verilmeyecektir.

İşkodra'y1 "Hazret-i Fâtih'in bir yâdigâr-ı zafer ve fütûhâtı" olarak tanımlayan Ali Saib Bey, vilayetin sınırlarını Rumeli kıtasının kuzeybatısında, kuzeyde Karadağ, doğuda Kosova, güneyde Manastır ve batıda Adriyatik Denizi olarak vermekte; yaklaşık 240.000 olan nüfusun 138.000'inin Müslüman, 112.000'inin ise Hiristiyan olduğunu belirtmektedir ${ }^{21}$. Machiel Kiel, İşkodra'nın Osmanlı hakimiyeti altına girişini şu ifadelerle anlatır: "1360-1393 yullarında Sırp Balšić Prensliği’nin merkezi olan şehir, Osmanlı kumandanı Kavala Şâhin tarafindan ele geçirildiyse de (1393-1396) bu uzun sürmedi. 1396'da George Stratsimirović şehri Venedikliler'e satt. Şehri tahkim eden Venedikliler 1479'a kadar burayı ellerinde tuttular. Osmanlılar, başarısı geçen birçok teşebbüsün ardından bizzat Fâtih Sultan Mehmed'in de katıldı̆̆ı uzun bir kuşatmadan

18 Arnavutluk bölgesi ile ilgili yazılan layihalar hakkında yapılmış bazı çalışmalar bulunmaktadır. Bkz. Kemalettin Kuzucu, "Layihalar Isığında Bağımsızlık Sürecinde Arnavutluk'un Sosyal ve Siyasal Durumu (1860-1908)", Türk Dünyası Incelemeleri Dergisi, C.XII/2, Kış 2012, ss. 309-332.

19 Ali Saib Bey Layihast, s. 20.

20 BOA, DH SAID.d, 150/78, s. 153.

21 Ali Saib Bey Layihası, s. 1. 
sonra İşkodra'yı ancak antlaşma ile alabildiler" "22. Ali Saib Bey, daha sonra Malisya ve Malisörler başlığı altında Malisya bölgesinin İşkodra'nın kuzeyinde bulunan 10 dağ ve 27 bayraktan $^{23}$ oluştuğunu söyler. Bu dağlar; Hot, Ğruda, Klemend, Kastrati, Eşkral, ma Loha Reç, Rapçe, Postriba, Temol Şalak’tır. Malisörler, gözü pek ve cesur kimselerdir ${ }^{24}$. Ancak burada Ali Saib Bey’in dokuz tane dağın ismini verdiğini görmekteyiz. İsmini vermediği dağ ise Şale Şoş'tur ${ }^{25}$.

\section{İşkodra'nın Siyasî ve İçtimaî Durumu ve Acil İhtiyaçları}

Bu açıklamalardan sonra "İşkodra'nın Ahvâl-i Siyâsiye ve İctimâ 'iyesi ve İhtiyâcât-ı Ácilesi" başlığı altında İşkodra hakkında genel bilgiler vermektedir. Bu verilerde özetle şu hususlardan bahsedilmektedir: İşkodra vilayeti, coğrafî konumu itibarıyla oldukça önem arz etmekle birlikte sahip olduğu potansiyelin aksine her türlü ilerlemeden mahrumdur. Osmanlı Devleti'nde bazı vilayetler vardır ki nedendir bilinmez merkezî hükûmetin dikkatinden kaçmış bir haldedir ki İşkodra da o meyanda kabul edilebilir. Geçtiğimiz birkaç aya kadar İşkodra adeta bir " $k l t$ ' $a-i$ mechûl" idi. Malisörler meselesi'26 bir dereceye kadar burada uyanış meydana getirdi. Buranın halkı tabiatları gereği haşin olmakla beraber 1slah ve idare edilmeleri zor değildir. Ancak hükûmetin tamamen lakayt davranması, yabancıların buraya da nüfuz etmesine ve bazı zararlı hareketlerin meydana gelmesine sebep oldu. Buranın halkı bugün iki şeyin tesirindedir ki bunlar cehâlet ve sefalettir. Bulundukları yer her türlü tarıma elverişli olduğu halde çoğu, hayvanlar gibi otlarla, ağaç kemirmekle hayatlarını idame ettirmeye çalışırlar. Avusturya ve İtalya

22 Machiel Kiel, “İşkodra”, DİA, C. 23, Türkiye Diyanet Vakfı Yayınları, İstanbul 2001, s. 433; Ayrıca İşkodra vilayeti ile ilgili ayrıntılı bilgi için bkz. İlkay Erken, Isskodra Vilayetinin İdari ve Sosyal Yapısı (1876-1912), Ondokuz Mayıs Üniversitesi Sosyal Bilimler Enstitüsü Yayımlanmamış Yüksek Lisans Tezi, Samsun 2014.

23 Mustafa L. Bilge'nin Diyanet İslam Ansiklopedisi'ndeki Arnavutluk maddesinde bayrak ile ilgili şu bilgiler verilmektedir: "Osmanl Devleti kabilelere bayrak veya sancak vermek suretiyle onları otorite olduklarını kabul ediyordu. Bu devirde konulan sisteme göre her kabile bir bayraktarın idaresi altında bulunuyor ve bu kabileler Osmanlı ordusuna her aileden bir kişinin katılmasıyla oluşturulan yardımcı kuvvetler gönderiyorlardı". Bkz. Mustafa L. Bilge, “Arnavutluk", DIA , C. 3, Diyanet Vakfi Yayınları, İstanbul 1991, s. 386.

24 Ali Saib Bey Layihast, s. 1.

25 İlkay Erken, İşkodra Vilayetinin..., s. 67.

261911 Malisör, bölgede önemli bir isyan çıkartmışlardı. 1911 Malisör isyanıyla ilgili ayrıntılı bilgi için bkz. Hasan Bello, Osmanlı ve Arnavut Kaynaklarına Göre Arnavutluk’ta 1911 Malisörler Ísyanı, Mimar Sinan Güzel Sanatlar Üniversitesi Sosyal Bilimler Enstitüsü Yayımlanmamış Yüksek Lisans Tezi, İstanbul 2009. 
birbirleriyle rekabet halinde burada yaşayanları kendi nüfuzları altına almaya çalışmakta$\operatorname{lar}^{27}$. Avusturya Konsolosluğu buraya senede 40.000-50.000 lira dolaylarında para aktarmakta ve bu meblağ senenin belli zamanlarında konsolos yahut piskopos ve papazlar marifetiyle yörenin önde gelenlerine ve muhtaçlara dağıtılmaktadır. Bu da zaten aç bî-ilaç olan bu bedbaht halkı esir hale getirmektedir. Bu iki devletin gerek merkezde gerekse kırsalda çok sayıda okul, kilise, yetimhane, hastane ve sanayi işletmeleri bulunmaktadır. Bu müesseseler, işinin ehli müdür, öğretmen ve papazlara teslim edilmiş, onlar da hizmet ettiği devletin nüfuzunu Osmanlı Devleti'nin memurlarının hâlâ görmediği, ayak basmadığı en ücra yerlere kadar genişletmeyi başarmışlardı. Yöredeki Müslümanların pek çoğu bu kimselere meyletmişlerdi, çünkü Müslümanlar, Hıristiyanlardan daha fazla cehalet ve fakr-u zaruretin pençesindeydiler. Muhtemelen bu sebepledir ki Malisya içindeki Müslümanlardan bir kısmının tanassur ettiği vakidir ${ }^{28}$.

Avusturya'nın bu faaliyetlerine bir örnek olması açısından İşkodra merkezdeki Baruçe Mahallesi'nde bulunan hastane dikkati çekmektedir. Hastanenin resmi ruhsat almasıyla ilgili belgede gerekli ruhsatın verilmesi kabul edilirken hastanenin planı da aynı belgede yer almaktadır. ${ }^{29}$ Hastanenin alt ve üst katının yerleşim planı ise şu şekildedir:

27 Avusturya, 19. yüzyılın ikinci yarısında Batı'da Alman Konfederasyonu'nu kaybetmesi üzerine özellikle 1870'lerden itibaren yönünü doğuya Balkan coğrafyasına çevirmiş ve burada hırslı bir yayılma politikası izlemeye başlamıştı. İtalya da bu dönemde birliğini tamamlamış ve sömürgecilik yarışına geç de olsa katılmıştı ve istediği topraklar Osmanlı Devleti'nin Balkan coğrafyasında kalan topraklarıydı ve doğal olarak Avusturya ile aynı bölgede hakimiyet sahasını genişletmek iki devlet arasında rekabete yol açacaktı. Bu noktada Balkan Savaşları esnasında bağımsız bir Arnavutluk devletinin kurulmasını istemekteydi ancak zayıf bir Arnavutluk istiyordu ki böyle bir durumda Arnavutluk'u kolayca ele geçirip Adriyatik Denizi'nin önemli noktası Otranto Boğazı'nın iki tarafına da egemen olarak bu denizi adeta kapalı İtalyan gölü haline getirebilsindi. Bkz. Fahir Armaoğlu, 19. Yüzyll Siyasî Tarihi (1789-1914), Ankara, Türk Tarih Kurumu Yayınlar1, 2003, s. 652, 671.

28 Ali Saib Bey Layihast, s. 1-2.

29 BOA, Irade Hariciye (I.HR), 422/20, leff 4, 16 Nisan 1326 (29 Nisan 1910). 


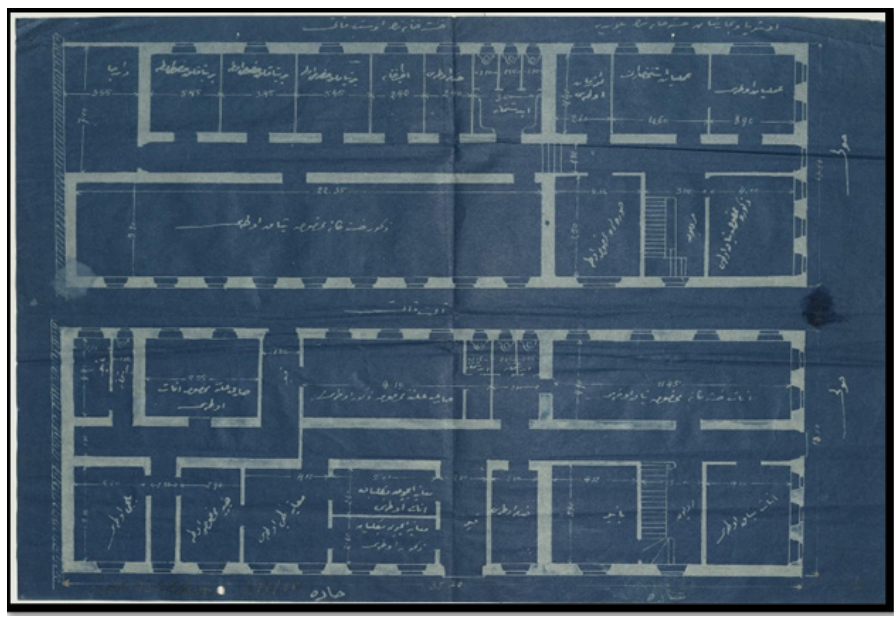

Şekil 1: Baruçe Mahallesi'ndeki Avusturya Hastanesi'nin kat planlarını gösterir çizim³

Arnavutluk'ta iki seneden beri devam eden hadiselerin etkisi, İşkodra havalisinde de görülmeye başladı. Müslüman ve Hıristiyan halkın Osmanlı Devleti'ne olan bağlılıkları çok azalmış durumdaydı. Çıkan olaylara devletin verdiği sert tepki ve şiddet buradakileri itaatten ziyade mukavemet göstermeye itti. Çünkü yapılan muamele ifrat-tefrit kabilindendi. Malisörler ve bütün İşkodralılar, Karadağ' 1 can düşmanı bilir ve onlarla çarpışırlarken birdenbire evlerini ve işlerini terk edip Karadağ' $1 n$ himayesine sığınmaları çok üzüntü vericiydi. İşkodra, uzun zaman boyunca yeterli askerî kuvvetten mahrum bırakıldığ1 gibi hükûmetin nüfuz ve muhabbeti birkaç tabur askerin sindirici gücü onlarda korku oluşturmamaktaydı. Şevket Turgut Paşa kumandasında, önceki sene lüzumsuz yere İşkodra'ya gelen 40-50 tabur askerin o civardaki faaliyeti ise maalesef yakıp yıkmaktan ibaretti. İki-üç ay kadar devam eden bu askerî harekât ve yakıp yıkma faaliyeti, herhangi bir fayda vermedi. Bu denli büyük bir kuvvetin birden İşkodra'yı terk etmesi, yapılması gereken 1slahatların maddî imkansızlıklar nedeniyle gerçekleştirilememesi halkın tekrar ayaklanmasına neden oldu. Harekât sonrasında yapılması gereken şey; halkın ihtiyaçlarını gözetmek, ihtiyaç duyulan yerlere askerî binalar yaparak içlerinde yeterli sayıda asker bulundurmak, yollar, okullar yapmak ve halka istihdam olanağı sağlamaktı. Bununla birlikte askerin bölgede olduğu müddet zarfında yapılanlarsa; nüfus sayımı, koyun sayımı ve silah toplatılmasından ibaretti ve bunların her biri halkın ruhuna, hayatına ve menfaatine dokunmaktaydı. Asayiş ne merkezde ne de kırsalda tesis edilemedi. Silahları toplatılarak ellerinden alınan halk, her tarafı açık olan sahillerden 
ve Karadağ'dan daha mükemmel silahlar elde etmekte hiç zorlanmadı. Çünkü Rusya ve İtalya'dan vapurlar dolusu gelmekte ve tanesi 5-10 kuruşa satılmaktaydı. Nüfus ve koyun sayımının sonucunda vergi alınmak istendi ancak buna hem Müslümanlar hem de Hıristiyanlar karşı çıktı.

İşbu vergiye Malisörler içinde Karadağ' a en yakın olup cesaretleriyle tanınan Hot ve Ğruda kabileleri itiraz ettiler. Karadağ da bu firsatı ganimet bildi ve bunları Karadağ'da bulunan akrabaları marifetiyle tahrik etmeye başladı. İtalya'nın yardımlarıyla Malisörlerin Karadağ'a firarları kolaylaşmaktaydı. Oraya giden Hot ve Ğruda Malisörlerinin iaşelerinin sağlandığ 1 ve kendilerine yevmiye tahsis edildiğini duyan diğer dağların halkı da Karadağ'a geçmeye başladılar. Sınırımız yerli halktan oluşan sınır bölüğü tarafından muhafaza edilmekteydi ve bunların da büyük kısmı Karadağ’a gidenlere katılarak onlarla gittiler. Tuz hadisesinin sebebi işte budur. Karadağ'ın özellikle de krallık unvanını aldıktan sonra Osmanlı Devleti'ne karşı tutumu dikkat çekmektedir. Bazı devletlerden gördüğü destek sayesinde, oldukça cüretkâr hareket etmektedir. Karadağ'ın tek amacı, bu gibi olayları firsat bilip önce Tuz havalisini ve daha sonra İşkodra'nın tamamını sınırlarına katmaktır. Çetine'deki Osmanlı elçisinin adeta bu devleti destekler biçimde yapılanlara kayıtsız kalması ise teessüf edilecek bir durumdur ${ }^{31}$.

Layiha yazıldığı esnada Osmanlı Devleti'nin Çetine'deki elçisi Sadreddin Bey'di. Sadreddin Bey, Hariciye Nezâreti Evrâk-ı Umûmiye Müdürü iken elçilik görevine 12 Mayıs 1910 tarihinde atanmışt1 ${ }^{32}$. Burada bir buçuk sene kadar görev yapan Sadreddin Bey' in yerine 13 Aralık 1911 tarihinde Alfred Rüstem Bey tayin edilmişti ${ }^{33}$. "Sadreddin Bey'in görevden alınmasında Ali Saib Bey’in görüşleri etkili olmuş mudur?” sorusuna cevap verebilmek mümkün olmasa da layihanı tarihiyle görevden alınmanın arasındaki yakınlık ilginç bir durum olarak ortaya çıkmaktadır.

İşkodra er geç Karadağ’’n saldırısıyla karşı karşıya kalacaktır. Onun için her şeyden önce ve derhal orada bulunan askerî kuvvetlerimizi düzenlememiz gerekmektedir. Şehrin savunulabilmesi için İşkodra merkeze altı kilometre mesafede olup daha önceden yapımına başlanılan istihkamların bir an evvel tamamlanması lazımdır. Karadağ, Boyana Nehri'ni İşkodra ile Çay Ağzı arasındaki müsait yerlerden köprülerle geçerek İşkodra-Şingin yolunu geçebilecektir. Ayrıca bir seferde yaklaşık 500 kişiyi nakledebilecek dört tane ufak vapuru da bulunmaktadır. Bu tehlikeye karşı İşkodra Gölü’nde ve

31 Ali Saib Bey Layihast, s. 2-4.

$32 B O A, \dot{I} . H R, 422 / 33$, leff 2, 29 Nisan 1326 (12 May1s 1910).

33 BOA, I.HR, 427/51, leff 2, 30 Teşrîn-i Sânî 1327 (13 Aralık 1911). 
nehirde ${ }^{34}$ işletilebilecek küçük topları bulunan birkaç vapur bulundurulması elzemdir. Olası bir savaş ilanında Karadağ'1n İşkodra mıntıkasında 30.000 kadar kuvvet sevk edeceği düşünüldüğünde; İşkodra, Kastrati ve Helim yolunun ve İşkodra-Merkut yoluyla Boyana Nehri'nin emniyette bulundurulması çok önemlidir. Sınırın Seliçe’den geçerek Gosine’ye kadar açık olduğu ve Tuz sınırı da gayr-i müstahkem bulunduğundan buralardaki asker sayısını arttırmak gerekmektedir. Vilayetin hiçbir yerinde düzgün yol olmadığından asker sevki ve naklinde görülen güçlük gerekenin yapılması noktasında bir uyanışa sebep olsa gerektir.

Malisör hadisesi nedeniyle İstanbul'dan gönderilen kuvvetler, üç-dört gün içinde Şingin iskelesine ulaşmıştı. Fakat orada kullanışlı bir iskelenin olmaması ve gerek Şingin-İşkodra yolunun bozukluğu, gerekse nehirde kullanılacak vapur ya da motorlu sandalların bulunmaması nedeniyle asker ve levazımat günlerce vapurlardan çıkarılamamış, İşkodra'ya sevk edilememişti. Özellikle de Tuz bölgesine asker ve malzeme sevkinde çok büyük zorluklar yaşanmaktaydı. Hem bu askerî sevkiyatları yapabilmek hem de yol yokluğundan fakr u zaruret içine düşen halkın ihtiyacını giderebilmek için öncelikle İşkodra-Şingin, İşkodra-Prizrin yolunun, akabinde Mirdita-Malisya ve Akçahisar-Petgra(?) ${ }^{35}$ yollarının yapılması gerekmektedir. İşkodra'nın gerek İstanbul gerekse civar vilayetlerle iletişimi, sadece Leş civarından geçen Tiran telgraf hattıyla yapılmaktaydı. Mirdita eşkıyası Seliçe’yi bastığında telgraf hattını tahrip etmişti ve haberleşme günlerce yapılamamıştı. Haberleşmenin yalnızca bir telle yapılmasındaki mahzur aşikâr olduğundan, İşkodra'dan Puka’ya ve oradan Prizrin'e ve Mirdita'ya merkez olacak Kuşan'a, Oroş ve Fand nahiyeleriyle Kanleb'e birer telgraf hattının acilen yapılması gerekmektedir. İşkodra Kalesi her ne kadar şimdiki harp aletlerine karşı yetersizse de Hazret-i Fâtih 'in Şâhin Yuvası olarak adlandırdığı kale, İşkodra'nın etrafıyla, Boyana ve Drin nehirlerine bir dereceye kadar hâkim olduğundan tamir ve tahkim edilmesi yerinde olacaktır. Ali Saib Bey, çoğu askerî alanda yapılması gerekenlerle ilgili görüşlerini şu cümlelerle sonlandırır: "Askerî yetkililerin gerçekleştireceği bu gibi hususlar hakkında görüş belirtmek haddim değilse de gerekli gördüğ̈̈m bazı hususları ifade etmemden dolayı beni affedin"36.

34 İşkodra Gölü ve Boyana Nehri’yle ilgili ayrıntılı bilgi için bkz. Yusuf Öztekin, XIX. Yüzyılda İşkodra Gölü ve Boyana Nehri (Siyasi, Ekonomik ve Uluslararası Hukuki Durumu), Ordu Üniversitesi Sosyal Bilimler Enstitüsü Yayımlanmamış Yüksek Lisans Tezi, Ordu 2014.

35 Her ne kadar metinde Petrga olarak verilmişse de emin olamadığımızdan ve haritalardan ilgili yeri tespit edemediğimizden metindeki yazılışını buraya vermeyi uygun bulduk.

36 Ali Saib Bey Layihası, s. 4-6. 


\section{Dukakin Kanunu}

Ali Saib Bey'in bundan sonra değindiği konu "Dukakin Kanunu” idi. Kanun hakkında detaylı açıklamalar yapan tahrirat müdürü, kanunun özelliklerini ve uygulanışını şu şekilde anlatmaktadır: Malisya bölgesinde "Dukakin" denilen kanun geçerlidir. Bu kanun ne Bâb-1 Âli ne de mahallinde kayıtlı değilse de kanun hakkında bazı bilgiler vermek faydalı olacaktır. Elde edilen bir iki genel taahhütname ve dağ komisyonunun belirlediği kararlara nazaran cinayet ve arazi davaları hariç diğer hukukî ve cezaî konular dağ komisyonunun yetkisi altındaydı. Bu komisyona her dağ reisi dönüşümlü olarak birer kişiyle katılmakta, bir başkan ve bir de kâtip bulunmaktaydı. Reislere hükûmet tarafından 10 'ar kuruş yevmiye verildiği gibi başkan da 500 kuruş maaş almaktadır. Hükûmet tarafindan görevlendirilmiş ve ilgili dağa bağlı bir bölükbaşı da işlerin yürütülmesinden sorumluydu. Gördükleri davalardan çeşitli miktarlarda vergi almakta ve toplanan bu vergiler yine heyet arasında bölüşülmektedir. Taahhütnameye aykırı davrananlardan alınacak olan nakit ceza bedeli de heyete aittir. Öldürme, yaralama ve silah çekme suçunu işleyen kişiler, bölükbaşıların ilgili mahalle gitmelerini müteakip 24 saat içinde teslim edilmediği veya kaçtığı takdirde, ona memleketin asayişini ihlâl etmiş gözüyle bakılarak bütün eşyası ve hayvanları müsadere edilerek evi yakılırdı. O gibilere yardım edenler, firarını sağlayanlar ve saklandığı yeri haber vermeyenler de aynı cezaya çarptırıldıkları gibi varisleri de o bayraktan sürülürdü. Katilin Osmanlı Devleti sınırları dışına çıktığı haber alınırsa, evindeki babası, erkek kardeşleri ve büyük oğulları tutuklanarak hapse gönderilir ve evleri yakılarak eşyası müsadere edilirdi. Hangi nedenle olursa olsun, para cezasına çarptırılanlar parayı ödemedikleri takdirde ilâ-nihâye hapiste kalırlardı. İşte özetle belli özellikler ifade edilen Dukakin kanunu medeniyete ve insanlığa sığmayacak bazı hükümler içerse de yalnız dağlardaki bayraklarda değil, bölgenin genelinde tercih edilmektedir. Burada hukukun bir an evvel yürürlüğe girmesi noktasında sulh mahkemelerinin acilen faaliyete başlaması gerekmektedir. Henüz nizamiye mahkemelerinden mahrum olan Puka ve Mirdita kazalarında birer bidayet mahkemesinin teşkili ve üyelerinin belli bir süre için yerli kimselerden seçilip atanmaları da uygun olacaktır ${ }^{37}$.

\section{Maarif}

Bu başlık altında yapılan ilk tespit, İşkodra vilayetinin maarifin feyzinden mahrum olduğudur. Eğitim için oldukça önemli meblağda tahsisat verilmekteyse de bu paranın ya nereye harcandığı bilinmemekte ya da ilgili memurların yörenin ihtiyacını doğru olarak tespit edememesi nedeniyle her sene ayrılan paranın büyük kısmı boş yere

37 Ali Saib Bey Layihast, s. 6-7. 
gitmektedir. Gerçi bazı köylerde eskiden kalan iptidai okulları olsa da buralarda okula dair hiçbir faaliyet görülmemektedir. Maaşları 150 kuruştan ibaret olan öğretmenler arasında Osmanlı Türkçesi’ni bilmeyenlerin sayısı çok fazladır. Zaten o maaşa daha yetenekli ve işinin ehli öğretmen bulmak da imkansızdır. Bu okulların eğitim vermekten ziyade cehalet ve zararlılık aşıladıkları şüphesizdir. İşkodra'da açılan "dârü'l-mu 'allimîn"in öğretmen yetiştirmesi hedeflenmekteyse de öğretmenlerin maaşları 100-200 kuruş arasinda olduğu müddetçe buraya rağbet edecek öğretmen temini mümkün değildir.

Buradaki darülmualliminin yatılı okul haline getirilmesi, idadi okul sınıfının yediye çıkartılması ve Mirdita'yla Leş malisyasına yakınlığı nedeniyle Zadrime nahiyesinde, bir de İşkodra merkezinde birer yatılı iptidai mektebinin kurulması elzemdir. Bu okullara köylerden gelecek olan öğrencilere de birer-ikişer kuruş yevmiye verilerek teşvik edilmesi, eğitimle ilgili yapılması gereken önemli işlerdendir. Daha önce kararlaştırıldığ üzere Malisya'nın her bayrağında bir iptidai mektep açmak elzemdir. Şu kadar ki okullara cins ve mezhebine bakılmaksızın tayin olunacak öğretmenlere maaş verilmesi, yetenekli kimselerden seçilmesi ve hükûmetin beklentilerini telkin etmelerinin sağlanması gerekmektedir. Ali Saib Bey'in şahsî kanaatine göre İşkodra'da büyük ölçekli bir sanayi mektebinin açılması şu anda var olan idadi mektebinden daha fazla faydalı olacaktır. Sebebi ise; halkın cehalet ve fakirliği nedeniyle çocuklarının senelerce okul derslerini takip edebilmeleri mümkün olmadığı gibi veliler de sekiz-on senelik bir eğitimin evlatlarına sağlayacağı faydayı takdirden acizdirler. Çünkü veli, çocuğunu okula göndermektense dağdan odun kesip getirmek, koyunlarını otlatmak, çift sürmek ya da hizmetçiliğe vermek gibi gelir getiren işlerde kullanmayı tercih etmektedir. Bunun için bir sanayi mektebi açılması ve parasız olarak öğrenci alması durumunda, bir yandan kendilerine rüştiye derecesinde ders gösterilmesi diğer yandan da ilerde geçimlerini sağlayacak bir sanatın öğretilmesi mümkün olabilecekti. Sanayi mektebine devam edecek öğrenci hem yevmiye alacak hem de ürettikleri üründen pay alacak ve yedi sekiz senede elinde epey bir parayla mezun olarak, bu parayı sermaye yapıp kendi işlerini kurabileceklerdi ${ }^{38}$.

Aslında Ali Saib Bey'in raporunda belirttiği bu hususlar, birkaç ay evvel İşkodra maarif meclisi müdürlüğü tarafından ifade edilmişti. Şöyle ki; İşkodra Valisi 20 Temmuz 1911 tarihinde İşkodra maarif müdürlüğünün 17 Temmuz 1911 tarihli takririne atıf yaparak buradaki darülmüallimin okulunun yeni eğitim öğretim y1lında yatılı hale getirilmesi, bunun için İstanbul Darülmuallimin Rüştiyesi'nden iki daimî öğretmenin daha atanması gerektiğini ifade etmekteydi. Ali Saib Bey’in maaşların azlığı konusuna da bu 
yazıda değinilmekte, öğretmenlerin 150'şer kuruş olan maaşlarının 500 kuruşa çıkartılmasının gerekliliğinden bahsedilmektedir ${ }^{39}$.

\section{Nafia}

Ali Saib Bey, İşkodra’nın nafia hizmetleriyle ilgili çok olumsuz görüşlere sahipti. Görüşlerini aktarmaya; "Nâfi 'a denilince insanda gayr-i ihtiyârî bir te'essür uyanmamak kâbil olamıyor" ifadeleriyle başlayan tahrirat müdürü köyler ve kasaba yollarını bir tarafa bırakın merkezdeki caddelerin bile geçilemeyecek bir halde olduğunu ifade etmektedir. Nafia Nezâreti, İşkodra gibi unutulmuş yerlere gönderdiği tahsisat sorunlara çözüm bulmaktan daha çok “def-i belâ” kabilindendi. İşkodra' da nafıa adına yapılmakta olan tek iş, senelerden beri yapımı devam eden İşkodra-Şingin yoludur. Yolun tamamı 46 kilometre olup, merhum Mustafa Âsım Paşa zamanında yapımına başlandığ 1 halde hâlen tamamlanamamıştır. İnşaat mevsiminin geçmesinden sonra verilen az miktarda tahsisat ile bir senede yolun bir-iki kilometresi yapılmakta, fakat bir sonraki seneye kadar yapılan yer de sellerden harap olup gitmekteydi. Çok şükür yolların genel olarak yapılması için verilen büyük tahsisat ile bu yol da 1327 senesi sonuna kadar tamamlanmak üzere geçen sene bir şirkete ihale edilmişti. Çok sayıda müracaat olması üzerine şirket memurları iki-üç ay önce İşkodra'ya ancak gelebilmişler ve belki de henüz ancak profil düzenlemeye vakit bulabilmişlerdir. Yol yapabilmek için para gerekmekte, gerektiği kadar para istemek de yapılacak yolun güzergahını tayin edip harita ve profillerini zamanında düzenlemekle olmaktadır. Mülkiye, askeriye ve belediyenin her türlü işine tayin edilen bir mühendisle bir kondüktör bu kadar yoğunluk arasında ne profil çıkarmaya ne de keşif defteri hazırlamaya zaman bulamamakta ve böylece nafia işleri için ayrılan paralar da heba olup gitmektedir. İşkodra' daki yol problemi diğer yerlerden çok fazlaydı. Öyle ki kaza merkezlerine bile yük ve binek hayvanıyla gitmek neredeyse imkansızdı. Buraya aylık 4.500 kuruş maaşla Fransa'dan gelen kondüktörlerden tayin edilen bir mühendis muavini varsa da bu kişiyi memurdan saymak doğru değildir. Zira kendisi ne zaman bir yolun keşfi ya da inşasıyla görevlendirilse ya mevkiin sarplığını ya da halkının haşinliğini bahane etmekte, bu gibi yerlere gitmek için taahhütte bulunmadığını söyleyerek görevden kaçmaktadır. Bu haliyle, mühendis muavininin varlığıyla yokluğu eşittir. Maaşı, yevmiye ve harcırahıyla neredeyse 6.000 kuruşu bulan bu kişiye karşılık hiç olmazsa Osmanlı tebaası bir-iki mühendis ve bir-iki kondüktör istihdamı daha yerinde olacaktır ${ }^{40}$.

39 BOA, Dahiliye İdare (DH.ID), 139/1, leff 5, 7 Temmuz 1327 (20 Temmuz 1911).

40 Ali Saib Bey Layihası, s. 9-10. 
Ali Saib Bey'in yabancı kondüktör, mühendis ve mühendis muavinleri için kullandığı bu olumsuz ifadelerin elbette doğruluk payı vardır ancak resmî belgelere yansıyan bazı olaylar, Osmanlı Devleti vatandaşı olan görevlilerin de işlerini yaparken çok zorlandıklarını göstermekteydi. Layihanın yazıldığı tarihten üç gün önce, İşkodra mühendislerinden Kadri Efendi şu hususlara değinmekteydi: İnşasına devam ettiğimiz İşkodra-Tuz yolunda çalışırken yüzden fazla sayıda olan Koplik Malisörleri silahlarıyla üzerimize hücum etti. Çalışanlardan çok sayıda kişi yaralandı ve tedavi için merkez vilayete döndüler. Yakın köylerden çalışacak işçi temini ve bir daha böyle müessif olayların olmaması için gereken tedbirlerin alınması gerektir ${ }^{41}$. Nafia Nazırı'nın durumu Sadaret'e bildirmesinden bir gün sonra, Sadaret Müsteşarı tarafindan Dâhiliye Nezâreti'ne durum bildirilerek, gerekli tedbirlerin bir an evvel alınmasını istendi ${ }^{42}$. İşkodra Valisi de 20 Kasım 1911 tarihi itibariyle olaylara karışan Koplik Malisörlerinin " $u s \hat{u} l-i$ cibâle" göre cezalandırıldığı ve asayişin sağlandığını bildirdi³. Ancak 14 Ocak 1912 tarihinde İşkodra Valisi Nedim Paşa tarafından gönderilen şifre yazıda, Ali Saib Bey’in sürekli değindiği mahallî dili bilmemenin bu olaya neden olduğu ortaya koyulmaktaydı ki mühendis Kadri Efendi yerel dili bilmediğinden, kendisinden iş istemeye gelen kalabalıkla aralarında çıkan anlaşmazlık neticesinde olayların patlak verdiğini ifade etmekteydi ${ }^{44}$.

İşkodra tabiatı itibariyle çok zengin göl ve nehirlerle çevrilidir. Bölgenin gelişimi için bulunmaz nimet olan bu doğal kaynaklardan yeterince faydalanılamadığı gibi İşkodra bu göl ve nehirlerin taşması nedeniyle zarara uğramaktadır. Drin, Boyana ve Mat nehirlerinin her biri seyr-i sefaine ve elektrik üretimine uygun nehirlerdir. Ancak nehir yataklarının taşkınlara karşı setleri olmadığından, her sene bahar mevsiminde taşarak pek çok yeri, özellikle de Zadrime bölgesini tahrip etmekte, zaten durumları kötü olan halkı perişan etmektedir. Nafia Nezâreti'nin İşkodra vilayetinde yapması gereken hizmetlerden ilki, bu nehirlerin temizlenerek yataklarından taşmasının engellenmesidir. Bunun için harcanacak paranın, suların istilasından kurtarılacak olan arazilerden elde edilecek olan gelirle tazmini mümkündür. Küçük vapurlar kışın İşkodra iskelesine kadar gelip gittikleri halde, suların çekildiği zamanlarda Çay Ağzı denilen mevkii geçememekte ve bütün nakliye Londra adı verilen kayıklar vasıtasıyla çok zor bir şekilde yapılmaktadır ki bu sıkıntıyı gidermek için tarak vapuru gerekmektedir. Burada bir nehir idaresi kurulsa ve bir-iki küçük vapur satın alınarak Şingin-İşkodra arasında sefer düzenlense hem bölge hem de genel olarak ülke için çok faydalı olacaktır ${ }^{45}$.

\footnotetext{
$41 B O A,(D H . I D), 25 / 9$, leff 6, 1 Teşrîn-i Sânî 1327 (14 Kasım 1911).

42 Aynı Belge, leff 7, 2 Teşrîn-i Sânî 1327 (15 Kasın 1911).

43 Aynı Belge, leff 12, 8 Teşrîn-i Sânî 1327 (21 Kasın 1911).

44 Aynı Belge, leff 19-1, 1 Kânûn-1 Sânî 1327 (14 Ocak 1912).

45 Ali Saib Bey Layihast, s. 11.
} 
Ali Saib Bey’in bu fikirlerinin de ilerleyen süreçte hayata geçtiği görülmektedir. Ticaret ve Ziraat Nezâreti'nden Sadaret'e gönderilen 25 Mayıs 1912 tarihli belgede, İşkodra'da yapılması kararlaştırılan ıslahat çerçevesinde Şingin-Obot arasında iki, Obotİşkodra ${ }^{46}$ arasında iki ve İşkodra Gölü’nde seyrüsefer yapmak için iki olmak üzere toplam altı adet istimbotun temininin istendiği ifade edilmekteydi. Yazının devamında, hâlihazırda İşkodra'da iki vapur bulunduğu, vapurlardan birinin Boyana Nehri'nde seyrüsefer etmek için İngiltere'ye sipariş edilen bir vapur, diğerinin ise Haliç Dersa 'âdet Şirketi'nden satın alınan ve Boyana Nehri'nde askerî hizmette kullanılmakta olan vapur olduğu belirtilmektedir. Bu vapurların altıya çıkartılabilmesi için; Obot-Şingin arasında işletilecek olan ve ikisi denize mukavemet edebilecek büyüklükte olması gereken dört geminin satın alınması ve yanaşacakları iskelelerin inşası için 30.000 lira gerekmekteydi. Bu paranın temini için gerekenlerin yapılması da Ticaret ve Ziraat Nazırı tarafından istenmekteydi ${ }^{47}$.

Ali Saib Bey’in İşkodra Gölü'nde çalışmalar yapmak üzere bölgeye gelmesini istediği tarak vapuru hakkında Sadaret tahrirat kaleminden Bahriye Nezâreti'ne gönderilen bir yazı; vapur taleplerinin mayıs ayından önce de olduğunu ortaya koyarken, göldeki seyrüsefer faaliyetleri ile ilgili daha ayrıntılı bilgi vermektedir. Belgede özetle şu bilgilere yer verilmekteydi: Büyük kısmı Osmanlı Devleti'ne ait olan İşkodra Gölü'nde sadece Karadağ'a ait vapurların seyrüseferde bulunmakta ve şehirle Şingin arasındaki nakliye, Karadağ ile Macar devletlerine ait iki şirket vasıtasıyla yapılmaktaydı. Bu da merkez sancağa bağlı Tuz kazası halkının her zaman vapur bulamamasına; İşkodra’ya çoğunlukla Podgoriça ve Karadağ yoluyla gidip gelmelerine neden olmaktaydı. Bu nedenle Seyrüsefain İdaresi tarafından İşkodra'da bir acente kurularak Şingin-Obot arasında işlemek üzere iki ve seyrüsefer için olmak üzere dört ufak vapurun ve Obot-İşkodra arasında işlemek üzere 20-30 santimetre su çeker iki ufak nehir istimbotunun ve Boyana Nehri'nin temizlenmesi için bir tarak vapurunun tahsis edilerek gönderilmesi gerekmektedir ${ }^{48}$.

Berlin Antlaşması gereğince iç sularda "kabotaj" uygulanması yasak olduğu halde ${ }^{49}$ mahallî idarenin göz yumması nedeniyle Boyana Nehri’nde "Loyd” ve "İtalya" şirketleri, Karadağ bandırasıyla teklifsiz bir şekilde kabotaj uygulamaktaydı. Ticarî nakliyenin ve asker sevkiyatının tamamı bu iki şirketin elindeydi. Orada bir "İâre-i nehriye" tesis

$46 \mathrm{Bu}$ hat üzerinde seferler yapılmakta ancak bu seferler İtalyan Polya vapur şirketi tarafindan gerçekleştirilmekteydi. Bkz. BOA, BEO, 3894/291989, 28 Nisan 1327 (11 Mayıs 1911); BOA, BEO, 3894/291989, 2 May1s 1327 (15 May1s 1911).

$47 B O A, B E O, 4049 / 303603$, leff 2, 12 Mayıs 1328 (25 May1s 1912).

48 BOA, BEO, 4025/301874, 28 Mart 1328 (10 Nisan 1912).

49 Berlin Antlaşması'nın 29. maddesi bu su yolları üzerinde bir "Serbestî-i ihtilat" hükmü getirmekteydi ki bu da her iki devletin kabotaj hakkının olmadığını göstermektedir. Bkz. Nihat Erim, Devletlerarası Hukuku ve Siyasi Tarih Metinleri, C. 1, Ankara, Türk Tarih Kurumu Yayınları, 1953, s. 416. 
edilip bir iki küçük vapur satın alınarak Şingin-İşkodra arasında işletilirse hem kurulan idare hem de devlet için çok büyük fayda sağlanmış olurdu. Mirdita'nın önemi son zamanlarda yaşanan olaylarla birlikte daha da açığa çıktığından, Seliçe'den Zaderima ve Mid ve oradan da Kuşan ve Orosna'ya kadar geçilmez olan yol ve köprülerle Tuz ve Puka yollarının ulaşıma bir an evvel açılması ve yapımına başlanan Akçahisar-Petgra(?) yolunun da tamamlanmasına gayret edilmesi gerekmektedir ${ }^{50}$. Akçahisar-Petgra(?) yolunun yapımına aslında çok zaman önce başlanmıştı. Konuyla ilgili Akçahisar Belediye Başkanı Hüseyin'in "İşkodra vilâyeti Draç sancağı dâhilinde Akçahisar kazâsının ahâlîsi nâmına" ifadesiyle imzalayıp Dahiliye Nezâreti'ne gönderdiği 1 Mayıs 1911 tarihli telgrafta; "şimdiye kadar kazâmızda bir metre şose yol yapılmadığı" ifadelerini kullanmakta ve Akçahisar-Petgra(?) yolunun güzergâhının dört sene önce yapıldığı ve işe başlanmasına rağmen yarım kaldığı bildirilmekteydi ${ }^{51}$.

Ali Saib Bey'in üzerinde önemle durduğu nehirlerin temizliğiyle ilgili layihanın kaleme alındığı tarihten iki ay kadar sonra, 31 Aralık 1911 tarihinde Sadaretten Dâhiliye Nezâreti'ne gönderilen yazıda; Boyana ve Drin nehirlerinin mecralarının temizlenmesi ve İşkodra Gölü'ndeki çalışmalarla ilgili teşebbüslerin bir an evvel gerçekleştirilmesiyle ilgili daha önceden bazı şartlar çerçevesinde düzenlenen mukaveleye binaen gerekli keşfi yapmış olan Reji Jenral şirketinin tebliğ tarihinden itibaren 15 gün içinde taahhütnamesini vermesini aksi halde yeniden ihaleye çıkılacağının belirtildiği bildirilmekteydi. Bunun üzerine söz konusu şirket, taahhütnameyi vererek gerekli incelemelerde ve bulunmak üzere bölgeye Mösyö Kapin'i gönderdi. Ancak Mösyö Kapin, İşkodra'da asayişin sağlanamayacağı hakkında bir raporla geri döndü. Yapılan müzakerelerde şirket vekili Mösyö Kapin'in bu raporunun yalnızca ilgili nehirlerin temizliği gibi işleri değil demir yolu yapımı gibi bölgeyi birinci derecede ilgilendiren diğer yatırımları da olumsuz etkileyeceğini ifade etti. Sadrazam, konuyla ilgili gerekenin yapılması hususunu Dâhiliye Nezâreti'ne ifade etti ${ }^{52}$.

\section{Ahvâl-i İnzibâtiye/Asayiş ${ }^{53}$}

Her yerde olduğu gibi İşkodra'da da hükûmetin asayiş noktasındaki tek dayanağı zabıtalardır. Önceden jandarmaların maaşları günlük geçimlerini bile karşılayamayacak kadar azdı ve çoğu zaman bu maaş da ellerine geçmezdi. Meşrutiyetin ilanıyla beraber bu konuda iyileştirmeler yapılmışsa da bu iyileştirmelerden faydalananların sayısı

50 Ali Saib Bey Layihast, s. 11-12.

51 BOA, DH.ID, 44/29, leff 1, 18 Nisan 1327 (1 May1s 1911)

52 BOA, DH.ID, 25/9, leff 17, 18 Kânûn-1 Evvel 1327 (31 Aralık 1911).

53 Layihada bu başlık olmayıp başlık kısmında kısa çizgi bulunmaktadır. Konuya binaen isim tarafımızca konulmuştur. 
sınırlıydı ve bu maaş alamayan ya da iyileştirme yapılmayan kişiler hükûmete karşı bir hareket içine girdiler. Burada yörenin her türlü işinde karar alıcı organ olan idarenin, bir jandarma askerini taltif etme ya da yer değiştirmeye veya bir mahalle sevk etmeye yetkileri yoktur. Özellikle de mülkî memurlara eskiden az da olsa gösterilen hürmet şu anda hiç yoktur. Vali, mutasarrıf ve kaymakamlar hiçbir iş yapmayıp yalnızca mülkî idarenin varlığını yok sayan jandarma kumandanlarını idare edebilseler kâfidir. Jandarmaların genç ve eğitimli olmasındaki fayda inkâr edilemez. Ancak İşkodra'da belli bölgelerde görevlendirilecek jandarmaların yerli halktan seçilmesi ve mahallî dili konuşabilmesi gerekmektedir. Selânik’ten gönderilen jandarmalar ise hemen tamamı çocuk yaşta ve bölgenin ne yaşayış tarzını ne de konuşulan dilini bilmemekteydiler. Bundan dolayı da işlerini yapamamakta ve belki de gittikleri yerden hakaret edilerek geri dönmekteydiler. Bu gibi hareketlerin önüne geçebilmek için bu jandarmaların yanına bir de tercüman vermek gerekir ki bu usulün menfi sonuçları olduğu daha önceki deneyimlerle açıktır. Zabıtanın etkisinin olmaması nedeniyle hemen her işte asker istihdamına, cebr ve şiddet göstermeye ihtiyaç duyulmaktaydı ki bu askerî disipline halel getireceğinden bir an evvel zabıtanın görev yapabilen bir hale getirilmesi gerekmekteydi. İşkodra Gölü'nün ve Boyana Nehri'nin ve Draç'a kadar olan sahilin tamamında ne karantina ne de inzibat bulunmamaktadır. Bu sahiller her türlü kaçakçılığa açık durumdadır. Arnavutluk bölgesine gelen silahların büyük kısmı İşkodra sahilinden getirilmektedir. Sahilin uygun yerlerinde ve bir diğerine yardım edebilecek mesafede birer gözetleme kulesi inşa edilmesi, bu kuleler arasında telefon hattıyla bağlantı kurulması ve bir-iki küçük vapur ve motorlu sandallarla sahilde daimî surette devriyeye çıkılması asayişin sağlanması noktasında önem arz etmektedir ${ }^{54}$.

\section{Ziraat}

İşkodra'nın arazisi oldukça bereketlidir ve her türlü hububat yetiştirilebilir. Ancak tarım yöntemleri eski usulde yapıldığı ve halk da maddî imkânsızlık içinde olduğundan, yeni tarım aletlerini alarak yeni usulde tarım yapmak bir yana tohum tedarikinde bile zorlanmaktadırlar ${ }^{55}$. Yörenin verimli arazisinden istenilen seviyede faydalanabilmek için vilayet merkezindeki ziraat bankasının sermayesin arttırmak, Seliçe, Tuz ve Şayak kazalarında da ziraat bankası şubesi açmak yerinde olacaktır. Halkın kendi parasıyla ziraî araç-gereç alamayacağı aşikâr olduğundan, vilayetin uygun yerlerinde depolar

54 Ali Saib Bey Layihası, s. 12-13.

55 Bölgedeki bu sıkıntılar önceki yıllardan beri devam etmekteydi İşkodra Valiliği'nden Dâhiliye Nezâreti'ne 5 Mart 1909 tarihinde gönderilen telgrafta Kavaye'ye gönderilen paranın yetmeyeceği, yemeklik için hemen 2.000 lira ve mevsimi geçmeden tohumluk için de yeterli miktarda paranın gönderilmesi gerekliliği vurgulanmaktaydı. Bkz. BOA, DH.MKT, 2766/93, leff 1, 20 Şubat 1324 (5 Mart 1909). 
kurarak gerekli aletleri halka taksitle satılması, bir-iki ziraat öğretmeninin bölgeye tahsisi ve bir de numune tarlası kurulması ziraatın gelişmesi adına çok faydalı olacaktır ${ }^{56}$. Ali Saib Bey'in numune tarlası fikrinin hayata geçtiğini görmekteyiz. Konuyla ilgili mazbatada, İşkodra'da bir numune çiftliği kurulmasının kararlaştırıldığı ve bunun için gerekli olan 500.000 kuruşun Ticaret ve Ziraat Nezâreti'nin 1912-1913 yılı bütçesine eklendiği görülmekteydi ${ }^{57}$.

Ali Saib Bey'in "Allah'in Osmanlı Devleti'ne bahșettiği doğal zenginliklerden birisi" olarak nitelendirdiği, İşkodra vilayetinin pek çok yerinde bulunan büyük ve eski ormanlar, maalesef ki ne korunabilmiş ne de onlardan istifade edilebilmiştir ${ }^{58} .80 .000$ hektar genişliğinde 40 kadar büyük ormana sahip olan vilayette, eğer bunlar hakkıyla işletilebilirse devlete ne kadar büyük fayda sağlayacağını izaha lüzum yoktur. Bu ormanlardan istenilen seviyede yararlanabilmek için yapılması gerekenler özetle şunlardır: Öncelikle sahillere doğru yol yaparak belirli birkaç yere dekovil hattı kurmak gerekir. Bazı ormanlarda bulunan ve her metreküpe 45-50 kuruş arasında vergi vermeyi taahhüt eden birkaç kişiden başka kimsenin bu işe girmemesinin sebebi anlaşılamamaktadır. Mevcut ormanların hiç olmazsa en büyüklerinin krokisi çıkarılsa ve işlettirilse çok iyi olur, ancak Orman Nezâreti bu konuyla maalesef ki hiç ilgilenmemektedir. Hâlihazırda 1.000.000 metreküp dolaylarında orman ürününün olduğu tahmin edilen vilayette, bu ormanlardan hakkıyla faydalanıldığından ülkeye büyük katkısı olacağı açıktır. Vilayet maden bakımından zengin olmakla beraber, bunları ortaya çıkarmak gerekmektedir ${ }^{59}$.

\section{Mülkî Teşkilât}

İşkodra'da mevcut kazalara ilaveten, merkez vilayet ile Eşkral nahiyesinde birer kaza teşkili ve bağlı köylerinin belirlenmesi hakkında önceden bir proje düzenlenerek Bâb-1 Âli'ye takdim olunmuştu ${ }^{60}$. Malisör meselesi nedeniyle nahiye teşkilatının buraya özgü bir şekilde yeniden düzenlenmesi gerekliliği ortaya çıkmıştı. İşkodra vilayeti, mevcut durumuyla Draç sancağıyla sekiz kazadan ve altı nahiyeden ibarettir. Malisya dahilinde bulunan nahiyeler ise; Hot, Kastrati, Kelmend, Reç ve Loha, Şale ve Şoş ve

56 Ali Saib Bey Layihast, s. 13.

57 BOA, MV, 227/89, 1 Nisan 1328 (14 Nisan 1912).

58 İşkodra ve Rumeli coğrafyasındaki diğer yerlerde bulunan ormanlarla ilgili bkz. Ahmet Başkan, 1876-1909 Balkan Vilayetlerindeki Ormanlar ve Ormancllık Faaliyetleri, Bitlis Eren Üniversitesi Mardin Artuklu Üniversitesi Sosyal Bilimler Enstitüsü Yayımlanmamış Yüksek Lisans Tezi, Bitlis 2016.

59 Ali Saib Bey Layihası, s. 13-14.

60 İşkodra'da Nahiye teşkilatıyla ilgili düzenlemelerle ilgili ayrıntılı bilgi için bkz. İlkay Erken, “İşkodra Vilayeti’nde Nahiye İdaresi'nin Uygulanması (1868-1912), Sosyal, Beşeri ve İdari Bilimler'de Akademik Araştırmalar-1, ed. Mehmet Yavuz Erler-Abdullah Şevki Duymaz, Gece Kitaplığı Yayınları, Ankara 2018, s. 185-200. 
Eşkral'dır. Bu nahiyelere ilave olarak, Mirdita'nın Oroş ve Fand bayraklarında ve Puka kazasının Karacadağ ve Akbale bayraklarında birer nahiye kurulması gerekmektedir. Karacadağ ve Akbale'nin ikinci sınıf müdürlük statüsüne alınması için 1325 senesinde irade çıktıysa da bugüne kadar tahsisat verilmedi ${ }^{61}$. Bunun yanında Oroş ve Fand bayraklarının nahiyeye çevrilmesi hakkında da yazışmalar çok sayıdadır. Malisya'daki nahiyelerin müdürlüğüne ilgili nahiye bayraktarlarının tayini kararlaştırılmışsa da bu görevi yapabilecek bayraktar yok gibiydi. O kişilerden müdür tayin etmek zarardan başka bir şey getirmeyeceği gibi kendi aralarındaki rekabetten kavga çıkartacaktır. Bu uygulama yerine, buralara İşkodralı Müslüman ya da Hıristiyanlarından yörenin diline aşina olan kimseler tayin edilmeli ve her nahiyenin bayraktarları da müdür yardımcısı olarak atanmalıdır. Bununla birlikte dağ reislerinin de bir şekilde taltif edilmesi gerekeceğinden, bu kimseler de her nahiyede oluşacak meclislerin üyeliklerine 100 kuruş maaşla getirilmelidir. Nahiyelerden başka, Mirdita, Puka ve Tuz kazaları idare meclis üyelerine de 200’er kuruş maaş verilmesi çok olumlu etki yapacaktır ${ }^{62}$.

\section{İşkodra'ya Tayin Olunacak Memurların Durumu ve Memurlar Hakkında Hükûmetin Yapması Gereken Muamele}

İşkodra'ya bir memur tayin edilir edilmez gerek ihtiyaç malzemelerinin pahalı olmas1 gerekse mevkiinin zorluğu nedenleriyle oradan geri dönmenin yollarını aramaya başlamaktadırlar. İşkodra gibi zor bir coğrafyada çalışacak ve yöreye vâkıf olmayan memurların bir-iki sene içinde dahi yöreye alışıp halkın ihtiyaçlarına cevap vermesi beklenemez. Yapılması gereken şey, oraya tecrübeli, iyi ahlâk sahibi ve mümkün mertebe mahallî dili bilen memurlar tayin etmektir. Bu memurlara geçimlerini sağlayacak maaşlar verilmeli ve memuriyetleri mümkün olan en uzun süre devam ettirilmeye çalışılmalı, terfileri geçirmeksizin yapılarak iki senede bir nakit ödülle taltif edilmelidir.

Burada yapılacak önemli faaliyetlerden birisi de mevcut memurlardan ehil olmayanları başka yere tayin ederek yerlerine yukarıdaki özelliklere sahip memurlar getirmektir. Valilerin memurlar hakkındaki olumlu ya da olumsuz görüşleri dikkate alınmalıdır. Avusturya Konsolosu'nun burada senede 40.000-50.000 lira kadar para harcadığ 1 dikkate alındığında, halkı kendine bağlamak için paradan daha etkili bir araç olmadığından İşkodra’ya hiç olmazsa 2.000 lira kadar para verilmelidir ${ }^{63}$.

61 İlgili yerlerin ikinci sınıf nahiye statüsüne getirilmesi Ali Saib Bey’in belirttiği 1325 yılında değil, bir sene sonra 1326 y1lında olmuştu. Bkz. BOA, I.DH, 1481/1, leff 2, 30 Mart 1326 (12 Nisan 1910).

62 Ali Saib Bey Layihast, s. 14-15.

63 Ali Saib Bey Layihast, s. 16. 


\section{İşkodra'da Takip Edilecek Siyaset}

Hemen bütün Arnavutluk bölgesinde olduğu gibi İşkodra vilayetinde de halkın neredeyse tamamı hükûmete karşı bir tavır içerisindedir. Bölge halkı tabiatı gereği şiddetle yola gelmeyeceği gibi gereğinden fazla yumuşaklıkla da istenilen netice elde edilemez. O bölgede bulunacak üst düzey devlet görevlileri, vakar ve azametlerini göstermeli, rastgele yumuşak hareketlerde bulunmamalı ve itidalden ayrılmamalıdırlar. Müslüman halkın ve onlardan daha fazla Hıristiyanların gönlünü almaya çalışmalıdırlar. Malisörler, Karadağ'dan döndükten sonra çok şımardıklarından, bu gibilere fazla yüz verilmemeli, ancak içlerinde devlete sadakat gösterenler bir işle görevlendirilmeli ya da küçük hediyelerle taltif edilmelidir. Üç-dört işinin ehli ve iyi maaş verilen seyyar doktor temin edilerek bölgeye gönderilmeli ve bu doktorlar sürekli köyler ve dağlarda göreve çıkarak hem yöre halkından hasta olanları tedavi etmeli hem de devletin propagandasını yapmalıdırlar.

İşkodra'daki konsolosların başvuruları kolaylaştırılmalı ancak usule uygun olmayan isteklerde bulunmalarının alışkanlık haline getirilmesi önlenmelidir. Konsolos tercümanlarının kimseye hissettirilmeksizin elde edilmesine çalışılmalıdır. Hıristiyan halk arasında papazların nüfuzu çok etkili olduğundan, ara sıra din adamlarına hediye ve ikramda bulunulmalıdır. Kasabalardaki ulemadan bazılarını belli zamanlarda Müslüman köylerine göndererek halkın devlete 1sındırılması noktasında tavsiyelerde bulunması sağlanmalıdır. Müslüman ve Hıristiyanların kanaat önderlerini tanıyıp, onlar aracilığıyla devletin oradaki nüfuzu sağlamlaştırılmalıdır. Senede 1.000 liralık zahire alınarak muhtaç durumda bulunan ailelere az da olsa verilmelidir ${ }^{64}$. Layihanın tarihinden hemen bir ay sonra böyle bir yardımla ilgili bir yazışma, devletin maddî olarak orada bulunan fakir halkı desteklediğini göstermektedir. 25 Kasım 1911 tarihli yazıda, bölgedeki Malisör olsun olmasın fakir halka verilmek üzere 50.000 lira tahsisat ayrıldığı görülmektedir. Yazının devamında, Malisörler için İşkodra vilayetine şimdiye kadar 50.000 lira gönderildiği ifade edilmekte, yöre halkında bu paranın peyderpey verildiği ve halkta herhangi bir huzursuzluğun görülmediği tespiti yapılmaktadır ${ }^{65}$.

\section{Sonuç}

Osmanlı Devleti'nde genç yaşta başladığı memuriyet hayatında değişik görevlerde hizmet eden Ali Saib Bey, uzun süre tahrirat müdürlüğü ve bir ara vali vekilliği yaptığı İşkodra'da önemli hizmetlerde bulundu. Malisör meselesinde gösterdiği yararlılık üzerine

64 Ali Saib Bey Layihast, s. 17-18.

65 BOA, HR.SYS, 150/7, leff 1, 12 Teşrîn-i Sânî 1327 (25 Kasım 1911). 
“İ̧skodra Heyet-i Tahkîkiyesi”nin başkanı ve Suriye Valisi Müşir Mehmed Kâzım Paşa tarafindan özel olarak davet edilerek yanında göreve gitmesi de buna delalet etmektedir. Ali Saib Bey' in yazmış olduğu bu layihayı küçük yaşlardan itibaren devletin çeşitli kademelerinde ve ülkenin çok değişik bölgelerinde görev yapması neticesinde oluşan tecrübenin bir sonucu olarak değerlendirmek gerekir. Layiha incelendiğinde, bölgeye ve bölge insanına hakimiyeti ortaya çıkmaktadır. Yöre sakinleriyle ilgili: "bölge halkı tabiatı gereği şiddetle yola gelmeyeceği gibi gereğinden fazla yumuşaklıkla da istenilen netice elde edilemez" ifadesi bu noktada dikkati çeker. Bölgede yapılan askerî faaliyetlerdeki orantısız güç kullanımını eleştirebilmesi, doğru bildiğini söyleme noktasında herhangi bir çekince göstermediğini ortaya koymaktadır. Merkezî hükûmeti de mahallî unsurları da açıkça eleştirmekten geri kalmaz. Eğitim, ziraat ve bayındırlık noktasındaki teklifleri, aslında yapılması gerekenlerle ilgili maddî kaynak sorununun ne kadar önemli olduğunu ortaya çıkarması açısından önem taşır. O, tespitleri yaptığı gibi bu tespitleriyle ilgili teşhislerde de bulunmaktadır. Layihada üzerinde durulan ve yapılması tavsiye edilen önerilerden bazılarının kısa süre sonra resmiyete kavuşması, layihanın doğru noktalar üzerinde durduğunu göstermektedir. Yapılan önerilerin yerine getirildiği hususlar arasında numune tarlası oluşturulması, fakir halka maddî destekte bulunulması gibi olaylar bulunurken eğitim noktasında üzerinde önemle durduğu sanayi mektebinin faaliyete geçmediği anlaşılmaktadır. Burada, layihada belirtilen hususlardan yerine getirilemeyenlerle ilgili aslında Osmanlı Devleti'nin girişimde bulunmak istediği ancak maddî imkansızlıkların buna müsaade etmediği görülmektedir. Layiha, özelde İşkodra'nın genelde ise Rumeli bölgesinin Osmanlı Devleti'nin elinden çıkmasıyla ilgili de bilgiler vermektedir. "Müslüman ve Hıristiyan halkın Osmanlı Devleti’ne olan bağlılıkları çok azalmış durumdadır ifadesi” oradaki insanların aidiyet duygularının derecesini gösterirken; Karadağ, Avusturya ve İtalya devletlerinin de bölgede gerek yaptıkları yatırımlarla gerekse karışıklık çıkartarak burayı Osmanlı Devleti’nden ayırmak için her türlü yol başvurduğu görülmektedir. Tüm bunlara rağmen Ali Saib Bey, İşkodra'nın daha iyi nasıl yönetilebileceği ve mevcut sorunlarının nasıl giderilebileceğiyle alakalı kafa yorarak bunu layihasında ayrıntılı bir biçimde açıklamaktadır. Ancak neticede ne bu layiha ne de Osmanlı Devleti'nin çabaları da sonuç vermeyecek ve Balkan Savaşları neticesinde İşkodra elden çıkacaktır.

Hakem Değerlendirmesi: Dış bağımsız.

Çıkar Çatışması: Yazar çıkar çatışması bildirmemiştir.

Finansal Destek: Yazar bu çalışma için finansal destek almadığını beyan etmiştir.

Peer-review: Externally peer-reviewed.

Conflict of Interest: The author has no conflict of interest to declare.

Grant Support: The author declared that this study has received no financial support. 


\section{KAYNAKÇA}

\section{Arşiv Kaynakları}

Ali Saib Bey Layihası, 16 Teşrîn-i Evvel 1327 (29 Ekim 1911).

\subsection{Türkiye Cumhuriyeti Cumhurbaşkanlı̆̆ı Devlet Arşivi Başkanlığı Osmanlı Arşivi (BOA) ${ }^{66}$}

Bâbiâli Evrak Odası (BEO)

Dahiliye Idare (DH.ID)

Dahiliye Mektubi (DH.MKT)

Dahiliye Mütenevvia (DH.MTV)

Dahiliye Defterler (DH SAID.d)

Dahiliye Şifre, (DH ŞFR)

Hariciye Siyasi, (HR.SYS)

Haritalar, (HRT.h)

Irade Dahiliye (I.DH)

Irade Hariciye (I.HR)

Meclis-i Vâlâ $(M V)$

\section{Araştırma Eserler}

Akyıldız, Ali: Tanzimat Dönemi Osmanlı Merkez Teşkilatında Reform (1836-1856), İstanbul, Eren Yayınları, 1993.

Armaoğlu, Fahir: 19. Yüzyll Siyasî Tarihi (1789-1914), Ankara, Türk Tarih Kurumu Yayınlar1, 2003.

Başkan, Ahmet: 1876-1909 Balkan Vilayetlerindeki Ormanlar ve Ormancllk Faaliyetleri, Bitlis Eren Üniversitesi Mardin Artuklu Üniversitesi Sosyal Bilimler Enstitüsü Yayımlanmamış Yüksek Lisans Tezi, Bitlis 2016.

Bello, Hasan: Osmanlı ve Arnavut Kaynaklarına Göre Arnavutluk’ta 1911 Malisörler İsyanı, Mimar Sinan Güzel Sanatlar Üniversitesi Sosyal Bilimler Enstitüsü Yayımlanmamış Yüksek Lisans Tezi, İstanbul 2009.

Bilge, L. Mustafa: "Arnavutluk", Türkiye Diyanet Vakfi İslâm Ansiklopedisi, C. 3, Diyanet Vakfi Yayınları, İstanbul 1991, ss. 383-390.

Erim, Nihat: Devletlerarası Hukuku ve Siyasi Tarih Metinleri, C. 1, Ankara, Türk Tarih Kurumu Yayınları, 1953.

66 Faydalanılan belgelerin numaraları ve leffleri dipnotlarda belirtilmiştir. 
Erken, İlkay: İskodra Vilayetinin İdari ve Sosyal Yapısı (1876-1912), Ondokuz Mayıs Üniversitesi Sosyal Bilimler Enstitüsü Yayımlanmamış Yüksek Lisans Tezi, Samsun 2014.

Erken, İlkay: “İşkodra Vilayeti'nde Nahiye İdaresi'nin Uygulanması (1868-1912), Sosyal, Beşeri ve İdari Bilimler'de Akademik Araştırmalar-1, ed. Mehmet Yavuz Erler-Abdullah Şevki Duymaz, Ankara, Gece Kitaplığı Yayınları, 2018, ss. 185-200.

Findley, V. Carter: Osmanlı İmparatorluğu'nda Bürokratik Reform Babıâli, 1789-1922, çev. Ercan Ertürk, İstanbul, Tarih Vakfı Yurt Yayınları, 2014.

Güneş, Mehmet: Osmanlı Devleti'nde Kaymakamllk (1842-1871), İstanbul, Kitabevi Yayınları, 2014.

İpşirli, Mehmet: "Kalemiye", Türkiye Diyanet Vakfi İslâm Ansiklopedisi, C. 24, Diyanet Vakf1 Yayınları, İstanbul 2001, ss. 248-249.

Kiel, Machiel: "İşkodra", Diyanet İslam Ansiklopedisi, C. 23, Türkiye Diyanet Vakfı Yayınlar1, İstanbul 2001, ss. 433-434.

Kuzucu, Kemalettin: "Layihalar Işığında Bağımsızlık Sürecinde Arnavutluk'un Sosyal ve Siyasal Durumu (1860-1908)", Türk Dünyası İncelemeleri Dergisi, C.XII/2, Kış 2012, ss. 309-332.

Kütükoğlu, S. Mübahat: Osmanlı Belgelerinin Dili (Diplomatik), İstanbul, Kubbealtı Neşriyat, 1998.

Kütükoğlu, S. Mübahat: "Lâyiha", Diyanet İslam Ansiklopedisi, C. 27, Ankara 2003, ss. 116-117.

Ortaylı, İlber: Tanzimat Devrinde Osmanlı Mahallî İdareleri (1840-1880), Ankara, Türk Tarih Kurumu Yayınları, 2000.

Öztekin Yusuf: XIX. Yüzyılda İşkodra Gölü ve Boyana Nehri (Siyasi, Ekonomik ve Uluslararası Hukuki Durumu), Ordu Üniversitesi Sosyal Bilimler Enstitüsü Yayımlanmamış Yüksek Lisans Tezi, Ordu 2014.

Seyitdanlıŏlu, Mehmet: Tanzimat Devrinde Meclis-i Vâlâ (1838-1868), Ankara, Türk Tarih Kurumu Yayınları, 1999. 


\section{EKLER}

\section{Ek 1: Ali Saib Bey'in layihasının transkripsiyonu}

\section{İşkodra Vilâyeti'nde İcrâsı Tasavvur Buyurulan Tedâbir-i Islâhiyeye Dâ'ir Ba'zı Ma'lûmât ve Mütâla'ât-ı Fâhirâne}

Hazret-i Fâtih'in bir yâdigâr-1 zafer ve fütûhâtı olan İşkodra vilâyeti Rumeli kıt'asının şimâl-i garbîsinde vâki‘ ve şimâlen Karadağ şarken Kosova cenûben Manastır ve garben Adriyatik deniziyle mahdûddur. 240.000 raddesinde olan nüfus-1 umûmiyesinden 138.000'i İslâm 112.000 mikdârı da Hıristiyandır.

\section{Malisya ve Malisörler}

Malisya k1t'ası İşkodra'nın cânib-i şimâlîsinde vâki' ve 10 cebel ve 27 bayrakdan ibâretdir. Cibâl-i Aşere: Hot, Ğruda, Kelmend, Kastrat, Eşkral, ma'a Lohareç, Rapçe, Postriba ve ma‘a Temal Şalak denilen cebellerdir. Malisörler ale'l-1tlâk kaviyyü'l-bünye cerî ve cûd bir kavimdir.

\section{İşkodra'nın Ahvâl-i Siyâsiye ve İctimâ‘iyesi ve İhtiyâcât-ı Âcilesi}

İşkodra vilâyeti mevki'-i coğrâfîsi i'tibârıyla pek mühimdir. Fevkalâde kâbiliyât-1 mevki'ası olduğu halde her türlü terakkiden mahrumdur. Ba' $\mathrm{z} 1$ vilâyetlerimiz vardır ki her neden ise hükûmet-i merkeziyenin enzâr-1 dikkatinden dûr ve mehcûr kalmışdır. İşkodra da o meyânda ta'dâd olunabilir! Şu birkaç aya gelinceye kadar orası âdetâ bir k1t'a-i mechûleden add olunabilirdi. Malisörler mes’elesi bir dereceye kadar mûceb-i teyakkuz ve intibâh olabilmişdir. Ahâlîsi teb'an haşin olmağla berâber idâre ve 1slâh halleri müşkül değildir. Ancak büsbütün denecek surette hükûmetin harekât-1 lâ-kaydânesi, ecnebîlerin oralarda da nüfuz ve hulûlüne ve birtakım muzır cereyânların zuhûruna sebeb olmuşdur. O havâlî ahâlîsi [s.2] bugün iki dâhiyenin taht-1 te'sîrinde lerzândır ki biri cehâlet diğeri sefâletdir. Bulundukları muhit hazâ'in-i tabî'iyetle mâlâmâl olduğu hâlde çoğu hayvanlar gibi otlarla, ağaç kabuğu kemirmekle idâme-i hayâta çalışırlar. Avusturya ve İtalya yekdiğerine rekâbet edercesine bunları dâ'ire-i nüfûzlarına almağa sâ‘îdirler. Avusturya konsolatosu senede kirk elli bin lira raddesinde para sarf etmekdedir. Senenin muhtelif zamânlarında konsolos yâhud piskopos veya papazlar ma'rifetleriyle rü'esâya ve muhtâcîne tevzî́ ve taksîm edilen bu meblăg zâten aç ve bî-ilâc olan bu bedbaht ahâlîyi gereği gibi esîr ve teshîr eylemişdir: Avusturya ve İtalya'nın gerek 
dâhil-i memleketde ve gerek kurâda müte'addid mektebleri kiliseleri eytamhâneleri hastahâneleri ve sanâyi‘hâneleri vardır. Bu mü’esseseler muktedir ve fa'âl müdürlere mu'allimlere, papazlara tevd'î olunmuş, onlar ise hizmet ettiği acentenin nüfûzunu me'mûrîn-i Osmâniyenin hâlâ göremediği, ayak basamadığı en hücrâ[ücrâ] yerlere kadar tevsî' ve ta 'mîme muvaffak olmuşlardır. Birçok İslâm rü'esâsı da bunlara mağlûb ve meclûbdur. Çünkü İslâmlar, Hıristiyanlardan daha ziyâde cehâletin fakr-u sefâletin müdhiş girdâbları arasında çarpınıb duruyorlar! Bu hâlin te'sîrâtından olmalıdır ki Malisya içinde bulunan İslâmlardan bir kısmının tanassur ettiği vâki ‘dir.

Arnavudlukda bir iki seneden beri cereyân eden vekâyi' in İşkodra havâlîsinde de aks-i te'sîri görülmeğe başlamışdır. İslâm ve Hıristiyân ahâlînin hükûmet-i Osmâniyeye olan râbıtaları pek ziyâde kesb-i za'af eylemişdir. Kuvâ-yı mertebenin her iki def'ada o hâvâlide ibrâz ve irâ'e ettiği satvet ve şiddet bunları itâ'atden ziyâde vâdî-i muhâlefet ve mukâvemete sevk etmişdir. Çünkü bu yapılan mu'âmele ifrât ve tefrit hâlinde güzerân olmuşdur. [s. 3] Malisörler ve bütün İşskodralılar Karadağ' 1 hasm-1 cân bilirler ve onlarla çarpışub dururlar iken Malisörlerin birden bire mesken ve me'vâlarını terk ile Karadağ'ın âğûş̧-1 himâyetine sığınmaları ne elîm bir hâdisedir. İ̧sodra birçok zamanlar kuvve-i kâfiyeden mahrûm bırakılmış iken yine hükûmetin nüfûz ve mehâbeti birkaç tabur askerin satveti anlarda bir hiss-i havf ve haşiyet uyandırmakdan hâlî değildi. Şevket Turgut Paşa kumandasıyla evvelki sene bilâ-lüzûm İşkodra'ya gelen kırk elli tabur askerin o havâlîdeki icra'âtı, yakup yıkmakdan ibâret kalmışdır. İki üç ay kadar devâm etmiş olan bu harekât-1 askeriye ve bu yakup y1kmak suretiyle olsun yine islahâta mukaddem olacak sûrette te'mîn-i menâfí' eylemekden hâlî kalmamış idi. Ne çâre ki o kuvve-i azîmenin birdenbire İşkodra'yı tahliye ile avdet etmesi ve ıslahât icrâsına da fikdân-1 mebâliğ ve vesâ'it hasebiyle imkân bulunamaması ahâlîyi ayaklandırmağa sebeb olmuşdur. Bu hareket bu şiddeti müte'âkib ahâlînin ihtiyâcâtı nazar-1 dikkate alınmak îcâb eden yerlerde mebânî-i askeriye inşâ ve içlerine mikdâr-1 kâfî asker ik 'âd edilmek, yollar mektebler yapdırılmak ve ahâlîyi i'âşe ve işfâh edecek işler istihzâr eylemek lâzım idi. Hayfâ ki askerin orada bulunduğu müddet-i cüz'iyeden bi' l-istifâde tahrîr-i nüfus ta 'dâd-1 ağnâm ve istirdâd-1 esliha gibi her biri ahâlînin rûhuna hayâtına ve menâfi' ine dokunan icraâtdan başka bir şey yapılamadı. Âsâyiş de kurâda ve cibâl dâhilinde takrir edilemedi! Silahları istirdâd olunan ahâlî, zâten her tarafı açık saçık olan sevâhilden ve Karadağ'dan daha mükemmel esliha, elde etmekde hiç müşkilâta uğramadılar. Çünkü Rusya ve İtalya'dan vapurlar dolusu gelen ve beş on guruşla satılan esliha bunları evvelkinden ziyâde teçhiz eylemişdir.

Tahrîr-i nüfusun ve ta'dâd-1 ağnâmın neticesi askere resm almakdan ibâret idi. Âna teşebbüs olununca İslâmda, Hiristiyânda umûmî bir hoşnutsuzluk görülmeğe 
başladı. Malisörler içinde Karadağ'a en yakın olan [s. 4] ve cesaretleriyle ma'rûf bulunan Hot ve Ğruda bayrakları işbu rüsûma en evvel muhâlefet etti. Karadağ da bu firsatı ganîmet bilerek bunları Karadağ'da bulunan akrabâ ve müte'allikâtı ma'rifetleriyle tahrik ve teşvîke müsâra'at eyledi. İtalya'nın inzimâm-1 mu'âvenetiyle Malisörlerin Karadağ'a firârlarını teslîh ve te'mîne muvaffak oldu. Oraya giden Hot ve Ğruda Malisörlerinin i'âş̧e ve teslîh edildiğini ve yevmiyeler aldığını duyub işiden diğer cibâl ahâlîsi de takım takım Karadağ'a geçmeğe başladılar. Hudûdumuz yerliden teşkil olunan hudûd bölüğü efradıyla muhâfaza edilmekde idi. Kısm-1 azâmı Malisör bulunan bu efrâd da onlara iltihâk ederek biri silahlarıyla berâber Karadağ'a geçdiler. Tuz hâdisesinin sebeb ve mebde'i işte budur!

Zâten Karadağ'ın hele krallık unvânını aldıkdan sonra Devlet-i Osmâniye'ye karşı ittihâz ettiği meslek şâyân-1 dikkat bir hâldedir. $\mathrm{Ba}^{\prime} \mathrm{z}$ devletlerden görmekte olduğu müzâheret, tezyîd-i cür'etine sebeb olmakdadır. Karadağ'ın maksad-1 yegânesi ve matamma'-1 nazarı bu gibi şûrişlerden istifâde ederek Tuz havâlîsini ve daha sonra İşkodra'yı mülküne ilâve eylemekdir. Çetine'deki sefirimizin âdetâ Karadağ'a meclûb denecek sûretdeki kayıtsızlı̆̆na te'essüf etmemek elden gelmez! Er geç, İşkodra Karadağ'ın muhâcemâtına ma'rûz kalacaktır. Onun için her vakitten ziyâde ve her şeyden evvel oradaki kuvvetimizi tanzîm ve tevsîk eylemek gerekdir. Şehrin bir ta'arruz-1 nâgihânîye karşı müdâfa'ası için altı kilometre mesafede inşâsı muktezi olan ve eyyâm-1 âhirede başlanılan istihkâmların bir an evvel vücûda getirilmesi lâzımdır. Karadağ'ın terakkiyât-1 hâzıresine göre Boyana Nehri’ni İşkodra ile Çay Ağzı arasındaki müsâ‘id mahallerden edevâtı mevcûd olan köprüleriyle [s. 5] geçerek İşkodra ile Şenkin tarikini kat` edebileceğinden ve def'aten dört beş yüz kişiyi nalk edecek dört ufak vapuru da mevcûd bulunduğundan buna karşı gölde ve nehirde işletilebilecek birkaç ufak ve toplarla mücehhez vapur bulundurulması kat'iyyü’l-vücûbdur. Kezalik harb vukû'inda Karadağ'ın İşkodra mıntıkasına otuz bin kadar kuvvet sevk edeceğine nazaran İşkodra, Kastrat ve Helim tarikinin ve İşkodra-Merkut tarikiyle Boyana Nehri'nin taht-1 emniyetde bulundurulması ehemm ve elzemdir. Hudûdun Seliçe'den bed'en ile Gosine'ye kadar açık olmasına ve Tuz hududu da gayr-i müstahkem bulunmasına binâ'en buralarda da tezâyüd-i tahfîze-i askeriye ittihâz ve icrâsı muktezîdir!

Vilâyetin hiçbir tarafinda muntazam yollar bulunmadığı cihetle sevkiyât ve nakliyât-1 askeriye husûsunda tesâdüf edilen müşkilât nazar-1 intibâhî açmış olsa gerekdir!

Malisör hâdisesi münâsebetiyle Dersa 'âdet'ten gönderilen kuvve-i imdâdiye, üç dört gün zarfinda "Şenkin" iskelesine yetişmiş iken gerek orada muntazam bir iskele 
olmamasından ve gerek Şenkin-İşkodra yolu yapılmamasından ve nehirde işleyecek vapur yâhud motorlu sandallarımız bulunmamasından nâşî o asker ve eşyâ günlerle vapurdan çıkarılamamış ve İşkodra'ya sevk olunamamışdır. Hele Tuz'a ya mevâki'-i sâ'ireye asker ve eşyâ sevk ve îsâlinde uğranılan müşkilât kâbil-i tasvîr değildir. Binâ'en-aleyh hem sevkiyât-1 askeriyeyi hem de en ziyâde yolsuzluktan dolayı düçâr-1 fakr ve sefâlet olan ahâlînin ihtiyâcâtı te'mîn edilmek için birinci derecede İşkodra-Şenkin, İşkodraPrizrin, derece-i sâniyede Mirdita-Malisya ve Akçahisar-Petgra(?) yollarının inşâsı lâbüddür. İşkodra'nın İstanbul'a ve vilâyât-i mütecâvire ile olan muhâberâtı yalnız Leş civarından geçen Tiran telgraf hattına münhasırdır. Mirdita eşkıyâsı Selçe kasabasını basdığı zamân telgraf hattını tahrîb etmiş ve muhâbere günlerle [s. 6] düçâr-1 inkıtâ‘ olmuş idi. Muhâberâtın bir tele münhasır kalmasındaki mahzûr ma'lûm olduğundan İşkodra'dan Puka'ya ve oradan Prizrin'e ve kezalik Mirdita'ya merkez olacak Kuşan ve Oroş ve Fand nahiyeleriyle Kanleb'e birer telgraf hattının temdîdi mevadd-1 müsta'cele cümlesindendir.

Her ne kadar şimdiki âlât-1 harbiyeye karşı metânet-i lâzımeyi hâ'iz değil ise de hazret-i Fâtih'in "Şâhin Yuvası" tesmiye ettiği İşkodra kal'asının, İşkodra'nın etrâf ve eknâfina ve Boyana ve Drin nehirlerine bir dereceye kadar hâkim bulunması cihetiyle şu hâlde âş̧iyâne-i bûm ve gurâb olan mezkûr kal'anın ta'mîr ve tahkîmi elzemdir.

"Cihet-i askeriyece takdîri lâzım gelen bu gibi husûsât için arz-1 mütâla'a haddim değilse de mücerred mağlûb-1 hissiyât olarak alâ- tarîkü'l-istitrâd vukû'bulan işbu ma'rûzâtımdan dolayı temennî-i avf eylerim!

\section{Dukakin Kanunu}

İsimleri bâlâda arz olunan Malisya kit'asında "Dukakin" kânunu denilen usûl cârî ve mer'îdir. Bu usûl ne Bâb-1 Âlîce ne de mahallince mazbût ve mukayyed olmadığı cihetle bu bâbda mücmelen ba'zı ma'lûmât arzı fâ'ideden hâlî değildir. Elde edilen bir iki ta'ahhüdnâme-i umûmî ve cibâl komisyonunun ittihâz ettiği mukarrerâta nazaran cinâyet ve arâzi da'vaları müstesnâ olmak üzere sâ'ir mevadd-1 hukûkiye ve cezâ'iyeyi rü'yet cibâl komisyonunun salâhiyeti tahtındadır. Bu komisyon her cebel rü’esâsından bi'l-münâvebe birer zâtdan ve bir de re'is ve kâtibden mürekkebdir. Rü'esâya taraf-1 hükûmetten onar guruş yevmiye verildiği gibi re'ise de beş yüz guruş ma'âş i'tâ olunmakdadır. [s. 7] Cibâlin vesâit-i icrâ'iyesi ise taraf-ı hükûmetten muvazzaf ve cibâle merbût olan bölük başılarıdır. Rü’yet ettikleri de 'âvîden îcâb ve tahammülüne göre aldıkları rüsûm yine bu hey'et arasında taksîm olunur. Ta'ahhütnâme hilâfına hareket edenlerden alınacak cezâ-yı nakdî kezalik hey'ete â'iddir. Usûl-i cibâl, şedîd-a'mâl 
olmakla berâber yine içlerinde mer'îdir. Katl ve cerh veyâ teşhîr-i silâh fí 'iliyle maznûn eşhas, bölük başıların mahall-i cürme muvâsalatlarından yirmi dört sa'âte kadar teslîm-i nefs edilmediği yâhud firâr eylediği hâlde âna memleketin yasasını ve âsâyişini ihlâl etmiş nazarıyla bakılarak emvâl ve eşyâsı ve hayvanâtı zabt ve müsâdere ve hânesi ihrâk olunur. O gibilere mu'âvenet ve firârını teshîl edenler, mahall-i ihtfâsını haber vermeyenler aynı cezâ ile tecziye ve vâris-i kibârları o bayrakdan tarda teb 'îd edilir. Kâtil ve mu'ayyen kâtilin Memâlik-i Osmâniye hâricinde bir mahalle savuşduğu haber alınır ise hânesindedeki peder ve birâderleri ve büyük oğulları der-dest ve habs ve hâneleri ihrâk ve emvâl ve eşyâsı müsâdere edilmek sûretiyle tazyîk ve tecziye olunur. Herhangi mes'eleden olursa olsun mahkûm olduğu cezâ-y1 nakdîyi i'tâda temerrüd edenler ilâ-nihâye taht-1 tevkîfde bırakılır.

İşte münhasıran arz olunan "Dukakin" kanunu havsala-i medeniyet ve insâniyete sığmayacak birtakım ahkâm-1 şedîde-i cezâ'iyeyi şâmil olduğu halde mücerred mahkemelerin tûl ve dırâz-1 müşkülâtına ma'rûz kalmamak için bugün yalnız cibâl değil o havâlînin bütün sükkânı bu usûlü tercih etmekdedir. Bu cihetle mahkemelerimizin ve usûl-ü muhâkememizin husûsiyle o havâlîde sslâh ve tanzîmi ve sulh mahkemelerinin bir an evvel teşkîliyle hukûk-1 umûmiyenin te'mîni esbâbının istihsâli derece-i vücûbdadır. Henüz mehâkim-i nizâmiyeden mahrûm bulunan Puka ve Mirdita kazalarında birer bidâyet mahkemesinin teşkili ve a'zâsının bir zaman için yerliden intihâb ve ta'yîni ilcaât-1 mevkî‘eye göre münâsib olacakdır.

\section{[s. 8] Ma'ârif}

İşkodra vilâyeti feyz-i ma'ârifden mahrûmdur. Ma'ârif nâmına oldukça mühim bir tahsîsât verilmekde ise de bu paranın sûret-i sarfi bilinememekden yahud me'mûrîn-i ma'ârifin ihtiyâcât-1 mahalliyeyi takdîr edememesinden dolayı seneden seneye bir hayli para bîsûd bir sûrette telef olub gitmekdedir. Gerçi devr-i sâbıkdan mürûr olarak ba'zı kurâda birer mekteb-i ibtidâ'î vardır. Lakin mektebe benzer hiçbir eser görülemez. Ma'âşları yüz, yüz elli guruşdan ibâret bulunan mu'allimleri meyânında ise lisân-1 Osmâniye bile vâkıf olmayanlar pek çokdur. Zâten o kadar ma âş̧a karşı daha ziyâde iktidâr ve evsâfı câmi' mu'allim bulmak imkân hâricindedir. Bu yoldaki mekteblerin neşr-i ma'ârifden ziyâde ta 'mîm-i cehâlet ve mazarrat etmekde olduğuna şübhe buyurulmamalıdır. İşkodra'da te'sîs edilen "dârü'l-mu 'allimîn"in mu'allim yetişdirmesi me'mûl ise de ma 'âşı yüz ile iki yüz guruş arasında bulundukça oralara rağbet edecek mu'allim tedâriki gayr-i kâbildir.

Dârü'l-mu'allimînin leylîye tahvili, i'dâdî mektebi sınıfının yediye iblâğ ve Mirdita ve Leş malisyasına kurbı hasebiyle Zadrime Nâhiyesinde ve bir de nefs-i İşkodra'da 
birer leylî ibtidâ'î mektebinin te'sîsi ve buraya kurâ ahâlîsinden devâm edecek tâliblere birer ikişer guruş yevmiye i'tâsı sâretiyle teşvîki cümle-i ihtiyâcâtı mahalliye-i ma'ârifdendir. Mukarrerât-1 âhire ile va'ad olunduğu üzere malisyanın her bayrağında da birer mekteb-i ibtidâ'înin te'sîsi zarûrîdir. Şu kadar ki bu mekteplere cins ve mezhebine bakılmaksızın ta'yîn olunacak mu'allimlere müstevfâ ma'âş verilerek onların erbâb-1 iktidârdan olmalarına ve âdetâ âmâl-i hükûmeti telkin edecek bir mesleği ihtiyâr etmelerine dikkat olunmalıdır. [s. 9] i'tikâd-ı kemterâneme göre İşkodra'da büyük mikyâsda bir sanâyi' mektebinin te'sîsi hâl-i hâzır için mekteb-i i‘dâdîden daha ziyâde memlekete te'mîn-i menfa'at eyler, esbâbına gelince ahâlînin cehâlet ve fakr u zarûretleri çocuklarının senelerce mekteb derslerini ta 'kîb etmesine gayr-i müsâ'iddir ve sekiz on senelik bir tahsîlin ne gibi menâfi“ te'mîn edeceğini takdîrden âcizdirler. Çünkü mektebe göndereceği çocuğunu dağdan odun kesip getirmek, koyunlarını otlatmak, çift sürmek ya hizmetçiliğe vermek gibi husûsâta sevki menfa'atlerine daha muvâfik bulmakdadırlar. Bunun için bir sanâyi“ mektebi te'sîs olunarak meccânen talebe kabûl edildiği hâlde bir tarafdan onlara rüşdiye derecesinde ders gösterilmek ve diğer tarafdan hâl-i istikbâlde ma'işetlerini te'mîn edebilecek birer san'at öğretmek gibi iki fâ'ide te'mîn edilmiş olacakdır. Sanâyi' mektebine devâm edecek talebenin gerek yevmiyeden ve gerek satışdan iktisâd edecekleri mebâliğ ise yedi sekiz sene zarfinda bir hayli yekûna bâliğ olacağından mektebden çıkacakları zamân ellerindeki o sermâye ile bir san'ata sülûk etmeleri daha ziyâde sa'âdetlerini te'mîn eder.

\section{"Nâfi'a"}

Nâf1'a denilince insanda gayr-i ihtiyârî bir teessür uyanmamak kâbil olamıyor. Nasıl kâbil olsun ki kurâ ve kasaba yollarından sarf-1 nazar umûmî caddelerimizin de geçilemeyecek bir hâlde bulunduğu hamişe manzûr dîde-i te'essür oluyor. Nâfi'â nezaretinin, husûsiyle İşkodra gibi unutulmuş mahallere seneden seneye tahsîs ettiği meblağ-1 cüz'î bir fầ'ide-i nâfi'a te'mîni için değil def'-i belâ kabilinden olduğuna bugünkü hâli şâhiddir. İşkodra'da nâfi'a nâmına senelerden beri yapılmakda olan yegâne bir yol vardır ki o da "İşkodra-Şenkin" tarîkidir. [s. 10] bu tarîk dolu dolu kırk altı kilometreden ibâret olub Mustafa Âsım Paşa merhûmun zamânında başlanmış olduğu hâlde henüz ikmâl edilememişdir. Mevsim-i ameliyâtın mürûrundan sonra verilen cüz'î tahsîsât ile bir sene içinde bir iki kilometrelik yol yapılmakda fakat ertesi seneye kadar ora hücûm-1 seylâb ile harâb olub gitmekdedir. Hamdolsun ki turuk-1 umûmiye meyânında tarik-i mezkûr dahi üç yüz yirmi yedi senesi nihâyetine kadar ikmâl edilmek şartıyla geçen sene şirkete ihâle olunmuş idi. Pek çok mürâca'ât ve tazyîkât üzerine şirket me'mûrları iki üç ay evvel ancak İşkodra'ya gelebilmişler ve belki de henüz daha profil tanzîmiyle meşgûl 
bulunmuşlardır. Yol yapabilmek paraya muhtâc, lüzumu kadar para istemek ise yapılacak yolların güzergâhını ta'yîn ve harita ve profillerini vakt ve zamânıyla tanzîme mütevakkıfdır. Mülkiye askeriye ve belediye nâmına her işe sevk olunan bir tek mühendis ile bir tek kondüktör ise ne yakın güzergâha ne de profil ve keşifnâme tanzîmine imkân bulamamakdadır. İşte bu sûretle nâfi'a nâmına verilen paralar telef olub gitmekde ve hiçbir iş görülememekdedir.

İşkodra vilâyeti bugün her yerden ziyâde yolsuzluk yüzünden bozulmağa giriftâr olmuşdur. Çünkü kaza merkezlerine bile hayvan ile gidip gelmek müte'assirdir demek olur ki ora nâfı'ası birinci derecede me'mûrîn-i fenniyeye muhtâcdır. Gerçi Fransa'dan gelen kondüktörlerden dört bin beş yüz guruşla bir mühendis mu'âvini de vardır. Fakat bunu me'mûrdan add etmek sahih olamaz. Zîrâ bir yolun keşfine yâhud inşasına me'mûr edildiği zaman mevki'in münâ'atından ahâlîsinin huşûnetinden bahs etmekde ve bu gibi yerlere gitmek için bir gûne ta 'ahhüdde bulunmadığını serd ile îfâ-yı hizmetten imtinâ' etmekdedir. Bu hâlde mühendis mu âvininin vücûduyla ademi müsâvî olmak gerekdir. Yevmiye ve harcırâhiye hemen ma'âşı altı bin guruşa bâliğ olan mu'âvin-i mûmâ-ileyhe mukâbil hiç olmaz ise bir iki Osmanlı mühendisi ve bir iki kondüktör istihdâmı daha ziyâde te'mîn-i maksada hâdimdir zann olunur!

[s. 11] İşkodra'da yapılması taht-1 vücûb-1 müsta 'celede bulunan yolların bir kısmı yukarıda arz olunmuş idi. Tabi 'atın o havaliye bahş ve ifâza ettiği bedâyi'-i gûnâgûndan biri de göl ve nehirleri olub bunlar memleketin her dürlü terakkiyât-1 medeniye ve iktisâdiyesine hâdim olacak bir hâlde iken ma'a-te'essüf İşkodra bu göl ve nehirlerin taht-1 istilâsında kalarak seneden seneye pek çok hasârâta dûçâr olmakdadır.

(Drin), (Boyana), (Mat) nehirleri ki seyr-i sefâ'ine, elektrik istihsâline müsâ'id nehirlerdendir. Yataklarının tuğyana karşı sedleri olmadığından her sene bahar mevsimlerinde tuğyân ve İşkodra'nın hele Zadrime ve Dağ Kenarı'na doğru birçok yerlerini tahrîb ile zâten fakir olan bîçâre ahâlîyi bir kat daha giryân ve perîşân etmekdedir.

Nâfi‘a nezâretinin İşkodra vilâyetine yapabileceği hizmetlerden en birincisi bu nehirlerin tahtîr ve islâhıyla men'-i mazarratına yol bulmakdır. Bu uğurda vukû'bulacak mesâr1fin taht-1 istilâdan kurtarılacak birçok arâzî bedelâtıyla tazmîn ve te'mîni muhakkakdır.

Küçük vapurlar kışın İşkodra iskelesine kadar amed ve şod edegeldikleri halde suların inhitâta uğradığg zamanlarda (Çay $A \breve{g} z ı)$ denilen mevkî‘'i geçememekde ve bütün nakliyât (Londra) tesmiye olunan kayıklar vâsıtasıyla ve kemâl-i müşkilât ile icrâ edilmekdedir. Bunun için bir tarak vapurunun vücûduna lüzûm-1 kat'î vardır. 
Berlin mu'âhedenâmesi mûcebince dâhilî sularda kapotaj icrâsı gayr-i câ'iz iken mücerred ihtiyâcât-1 mahalliye endişesine mağlûben hükûmet-i mahalliyenin ağmâzından nâşî Boyana nehrinde (Loyd) ve (Italya) kumpanyaları Karadağ bandırasıyla bilâ-tekellüf kapotaj icrâ etmekdedir. Bütün nakliyât-1 ticâriye ve sevkiyât-1 askeriye bu iki kumpanyanın elindedir.

Orada bir (İâre-i nehriye) te'sîs ve bir iki küçük vapur mübâya'a edilerek Şenkin ile İşkodra arasında işlettirilirse hem idâre hem de memleket için pek büyük fâ'ideler te'mîn edilmiş olur.

Mirdita'nın derkâr olan ehemmiyet-i mevki'esi vukû'ât-1 âhire ile hâlen daha ziyâde kesb-i nezâket eylemiş olduğundan Seliçe'den (Zadrime) ve (Mid) ve oradan da (Kuşan) ve (Orsona) kadar geçilmez olan yol ve köprülerin [s. 12] ve (Tuz) ve (Puka) yollarının mürûr ve ubûra ve nakliyât ve sevkiyât-1 askeriyeye sâlih bir hâle serî‘an ifrâğ1 ve başlanılmış olan Akçahisar-Petrgra(?) tarikinin de ikmâline gayret olunması muktezîdir.

Vilâyetin ahvâl-i inzibâtiyesine gelince her yerde olduğu gibi İşkodra'da da hükûmetin yegâne vâsıta-i icrâ'iyesi zâbıtadır. Devr-i sâbıkda jandarmaların ma'âşları kuvvet-i yevmiyelerini dahi te'mîn edemeyecek derecede kalîl olmakla berâber o da ellerine geçmez idi. Meşrûtiyetin cümle-i mehâsin-i mübeccelesinden olmak üzere lillâhi'l-hamd şimdi hem terakkiyâtı hem de tahsîsâtı tezyîd edilmiş olduğu hâde yine bunlardan istifâde mahdûd kalmış ve bu hey'et-i zâbita hükûmete karşı evvelkinden daha fenâ bir vaz'iyet almışdır.

Memleketin kâffe-i mesâ'il ve mes'ûliyetini tahammül etmek olan me'mûrîn-i idârenin bir jandarma neferini dahi taltîf yâhud tebdîle ve bir mahalle sevk ve tesyîre salâhiyetleri yokdur. Hele me'mûrîn-i mülkiyeye karşı devr-i sâbıkda bile diriğ edilmeyen ve netîce i'tibâriyle me'mûrînin enzâr-1 umûmiyede tezâyüd kadar ve haysiyetlerine hâdim olan cüz'î küllî ihtirâmâtın şimdi kâffesi kaldırılmışdır. Vali, mutasarrıf, kaymakamların hiçbir iş olmasa ma'iyetlerindeki siyâset-i mülkiyeden gâfil jandarma kumandanlarını idare ile uğraşması kâfidir.

Jandarmaların genç ve dinç olmasında ve mekteb görmesindeki muhsinât gayr-i kâbil-i inkârdır. Ancak İşkodra'daki husûsiyet-i mevki'eye mâlik olan yerlerde bulundurulacak jandarmaların herhâlde yerliden olmaları ve lisân-ı mahallîye âşinâ bulunmaları taht-1 vücûbdadır. Dersa ‘âdet’ten ve Selânik’ten gönderilen jandarmalar ise kâmilen denecek sûretde çocuk ve oranın misâk ve ma'işet ve seferiyesine gayr-i tahammül 
olmakla berâber ahvâl ve elsine-i mahalliyeye de vâkıf olmamalarından nâşî hiçbir iş görememekde ve belki gittikleri yerlerden dûçar-1 hakâret olarak avdet eylemekdedirler. Ale'l-ekser bunlara birer delil ve tercümân terfîkine mecbûriyet hâsıl olmakdadır ki bu hâlin inzibât-1 mahallîye olan su'-i te'sîri muhtâc-1 îzâh değildir. [s. 13] Zâbıtanın nüfûzsuzluğu yüzünden hemen her işde asker istihdâmına ve cebr ve şiddet irâ' esine mecbûriyet hâsıl olmakdadır. Bu ise satvet ve intizâm-1 askeriyeyi haleldâr edeceğinden zabıtanın bir hâl-i fa'âliye ifrâğ 1 çâresini aramak gerekdir. Gölün ve Boyana Nehri'nin ve Draç'a kadar bütün sevâhilin her tarafi vesâ'it-i tahaffuziye ve inzibâtiyeden hâlîdir. Bu sâhiller; her dürlü kaçakçılığa mâ'id birer girizgâhdır. Arnavudluk'a idhâl olunan eslihânın kısm-1 azamı İşkodra sevâhilinden ferceyâb-1 duhûl olmakdadır. Sevâhilin mevâki'-i münâsebesinde ve yekdiğerine mu'âvenet verebilecek sûretde birer tarassud kal'ası inşâ ve telefonla yekdiğerine rabt edilmesi ve bir iki küçük vapur ve motorlu sandallarla sevâhilin tarasudât-1 dâ'ime altında bulundurulması âsâyiş ve inzibât noktasindan pek ziyâde hâ'iz-i ehemmiyetdir.

\section{Zirâ'at}

İşkodra vilâyeti arâzîsi gayet münbit ve mahsûldârdır. Her nev' hubûbât yetişdirir. Yalnız usûl-i zirâ'at nâkıs ve ahâlînin fakr u zarûretleri âlât ve edevât-1 cedîde tedârik ve celbi şurda dursun tohum tedarikine bile gayr-i müsâ‘iddir. O feyyâz arâzîden lâyıkıyla istifâde edilebilmek için merkez vilâyetdeki zirâ'at bankası sermâyesinin tezyîdi ve Seliçe, Tuz, Şiyak kazalarında da birer zirâ'at bank şu 'belerinin te'sîsi lâzımdır. Ahâlînin kendi başlarına âlât ve edevât-1 zirâ'iye celb ve mübâya'asına kudretleri olmadığından vilâyetin münâsib mevki'inde birer depo ittihâzıyla lüzûmı kadar âlât ve edevâtın bi'lcelb ahâlîye taksit ile bey' ve füruht edilmesi ve bir zamân için bir iki de zirâ'at mu'allimlerinin bulundurulması ve bir de numûne tarlası vücûda getirilmesi pek fâ’idelidir.

Cenâb-1 feyyâz-1 mutlakın memalik-i Osmâniye'ye müstefîz ettiği havas-1 servet-i tabî‘iyeden biri de ormanlardır. Bu cümleden olmak üzere İşkodra vilâyetinin pek çok yerlerinde cesîm ve kadîm ormanlar vücûd olduğu hâlde [s. 14] hayfâ ki ne muhâfaza edilmiş ne de ândan istifâde olunabilmişdir. Seksen bin hektar vüs'atinde kırk kadar cesîm ormanlar vardır ki bunlar işletdirildiği hâlde devlete ve memlekete ne büyük servet ve sa'âdet tevlîd edeceği vâreste-i arz ve îzâhdır.

Bu ormanlardan lâyıkıyla istifâde edebilmek evvel bâ-evvel sâhillere doğru birer yol yapmak birkaç yerlerine de "dekovil" hattı temdîd eylemekle hâsıl olur. Ba 'zı ormanlara zuhûr eden ve beher metre-mik 'abda kırk beş- elli guruş raddesinde resim vermeği ta'ahhüd eden birkaç tâlibden hiçbirinin mes'ûlü is'âf edilmemesindeki sebeb bilinemez. 
Mevcûd ormanlardan hiç olmazsa en zengin ve büyüklerinin birer krokisini çıkarmak ve bunların işlettirilmesi esbâbını istihsâl etmek içinse Orman nezâretinin ciddî hiçbir teşebbüsde bulunmaması sezâ-yı te'essüfdür. Bugün tahammül-ü fennîsi sâbit olmak ve bir milyon metre-mik'aba karîb orman vardır ki satılması yâhud işlettirilmesi hâlinde hazîne-i devlet için ne kadar fâ'ide te'mîn edeceği bi'l-hesâb tezâhür eyler. İşkodra vilâyeti ma'den cihetiyle de zengindir. Yalnız bunları ta'kîb ve taharrî etmek gerekdir.

\section{Teşkîlât-ı Mülkiyesi}

Mevcûd kazalara ilâveten merkez vilâyette ve "Eşkral" nâhiyesinde birer kazanın teşkili ve ba'zı kurânın yekdiğerinden fekk-i irtibâtı hakkında vaktiyle bir proje tanzîm ve Bâb-1 âlîye takdîm olunmuş ise de Malisörler mes'elesinden dolayı âhiren ittihâz edilmiş mukarrerâta nazaran nevâhî teşkîlâtının îcâbât-ı mahalliyeye göre icrâsı lüzumuna mebnî o noktadan arz-1 mütâla'a zaruridir. [s. 15] İşkodra vilâyeti şu halde Draç sancağıyla sekiz kazadan ve altı nahiyeden ibârettir. Malisya dâhilinde bulunan nevâhî ise Hot Ğruda Kastrat Kelmend Reç ma'a Lohe Şale ve Şoş ve Eşkral'dan ibâretdir.

Bu nevâhiye ilâveten Mirdita'nın "Oroş" ve "Fand” bayraklarında ve Puka kazasının (Karacadağ) ve (Akbale) bayraklarında birer nâhiye teşkili îcâb eder. Zâten Karacadağ ve Akbale'de ikinci sınıftan müdüriyet teşkîli için üç yüz yirmi beş senesinde irâde-i seniyye südûr etmiş ise de her neden ise hâlâ tahsîsâtı verilmemişdir. Oroş ve Fand bayraklarının nâhiyeye kalbi hakkında pek çok muhâbere mesbûkdur.

Malisya dâhilindeki nevâhî müdürlüklerine o nâhiye bayrakdarlarının ta'yîni mukarrerât-1 vâk1'a cümlesinden ise de bayrakdarlar içinde müdüriyet vazifesini îfâ edecek hemen bir ferd yokdur. Onlardan müdür ta'yîni hükûmetce zarardan başka bir fâ'ide te'mîn etmeyeceği gibi sâ'ika-i rekâbetle kendi aralarında da bu yüzden gavâ'il zuhûrı müsteb“id değildir. Fikr-i fâhirâneme göre buralara yine İşkodra İslâm yâhud Hıristiyânlarından lisâna âşinâ kimseler ta'yîn ve her nâhiyenin bayrakdarlarının da müdür mu'âvini olarak istihdâm edilmesi, bununla berâber cibâl rü' esâsının birer sûretle taltîf ve celb-i amâlesi matlûb olmasına göre her nâhiyede teşekkül eden meclis a'zâlığ1na isimleri ma'lûm ve mazbût olan rü'esânın a'zâ sıfatıyla ve yüz guruş ma âşla münâvebeten devâm ettirilmesi daha muvâfik gibidir.

Nevâhîden başka Mirdita, Puka ve Tuz kazaları mecâlis-i idâre a'zâsının da müsteviyen ikişer yüz guruş ma‘âşla tavzifí pek ziyâde hüsn-ü te’sîr husûle getirecekdir. 


\section{[s. 16] İskodra'ya Ta'yîn Olunacak Me'mûrînin Ahvâli ve Onlar Hakkında Hükûmetce Yapılması Lâzım Gelen Mu'âmele}

İşkodra'nın galâ-yı es‘ârı metâ'ib ve meşâgil-i mevkî‘esi hasebiyle oraya gönderilen me'mûrlar muvâsalatlarıyla berâber oradan birer sûretle kurtulmak kaydına düşmekdedirler. İşkodra gibi bir muhit-i muzallem ve mechûl içinde bulunacak me'mûrun bir iki sene içinde ahvâl ve ihtiyâcât-1 mahalliye kesb-i vukûf eylemesine ihtimâl verilemez. Vukûfi olmayan bir me'mûrdan ise bittabi‘ hüsn-ü hizmet beklenemez. İşkodra'nın bir hâl-i intizâma ircâ‘'1 matlûb ise ora için en muktedir ve tecrübekâr ve hüsn-ü ahlâk ashâbından ve mümkün olduğu kadar lisân-1 mahalliyeye âşinâ kimselerden me'mûrlar intihâb ve ta'yînine begâyet i'tinâ eylemek gerekdir. Bu evsâf ile muttasıf olarak ta'yîn edilecek me’mûrlara müstevfâ ma‘âş verilmeli ve esbâb-1 mucibe-i sahîha olmaksızın oradan kaldırılmamalı ve mümkün olduğu kadar me'mûriyetleri temdîd edilmelidir. Fi'ilen ve maddeten ibrâz-1 hüsn-ü hizmete muvaffak olan me'mûrînin hakk-1 terfí‘i muhâfaza edilmekle berâber bir iki senede bir mükâfât-1 nakdiye ile taltîf ve teşvîk olunmalıdır.

İşkodra için evvel bâ-evvel yapılacak 1slahât me'mûrîn-i hâzıreden nâ-ehl olanların kaldırılarak yerlerine evsâf-ı ma'rûzayı hâ'iz me'mûrlar göndermek ve o muktedir ellerle icrâsı mutasavvır olan tedâbir-i 1slâhiyeyi esaslı bir sûretde te'sîs eylemek gerekdir. Bu me'mûrîn içinde en ziyâde rü'esâ-yı me'mûrîn-i mülkiye nazar-1 ehemmiyete alınmalı ve diğer sınıf me'mûrînin de her hâlde erbâb-1 iktidâr ve imtizâcdan olmasına dikkat edilmelidir.

Vâlilerin me'mûrîn hakkındaki şükr ve şikâyeti fakat müdellel olmak şartıyla kabûl ve ahvâl-i sâ'ireye dâ'ir olan iş 'ârâtı tervîc edilerek nüfûz ve haysiyeti a'lâ edilmelidir. Avusturya konsolatosunun senevî kırk-elli bin lira raddesinde para sarf etmekde olduğu yukarıda bi'l-münâsebe arz olunmuşidi. Celb ve teshîr-i kulûb için paradan mü'essir bir vâsıta olamayacağından İşkodra'ya da tahsîsât-1 mestûre nâmıyla hiç olmazsa iki bin lira para verilmelidir. Vâliler cihet-i askeriyeye karşı dâ'imâ himâye edilmelidir.

\section{[s. 17] "İşkodra'ca Ta'kîb Olunacak Siyâset"}

Bütün Arnavudluk’ta olduğu gibi İşkodra vilâyetinde de hemen umûmiyetle karîb sûretde ahâlî hükûmete karşı bir vaz'-1 bâridâne göstermekdedir. Anladığıma göre Arnavudların tabi'atı şiddete mütehammil olmadığı gibi lüzûmundan ziyâde hilm ve mülâyemete de müsâ‘id değildir. Oralarda bulunacak rü'esâ-yı me’mûrîn vakar ve azametini muhâfaza etmekle berâber rastgele dilşikenlikde bulunmamalı ve dâ'ire-i i'tidâlden ayrılmamalıdır. Gerek İslâm ahâlînin gerekse onlardan ziyâde hükûmetden 
mütevahhiş olan Hıristiyanların celb-i kulübüne çalışmalıdır. Malisörler Karadağ’dan avdetten sonra pek ziyâde şımarmış olduklarından bunlara oraca yüz vermemek ve büsbütün terbiyesiz bırakmamakla berâber içlerinde nâmuskârâne ve sâdıkâne hareket edenler birer iş ile tavzîf ve ufak tefek hediyelerle taltîf edilmelidir. İki, mümkün ise üçdört muktedir ve nâmuslu ve müstevfâ ma'âş̧ı seyyâr tabîbler ta'yîn olunarak bunları sûret-i dâ'imede kurâ ve cibâl dâhilinde dolaşdırılarak bir tarafdan ahâlînin hastalarını tedâvî diğer tarafdan propgandalar yapdırılmalı.

Oradaki konsolosların şâyân-1 kabûl-i mürâca'atlarını teshîl etmeli fakat usûle muvâfik olmayan mutâlibîni kabûle alışdırmamalıdır. Konsolos tercümânlarının kimseye hissettirilmeksizin birer sûretle elde edilmesine çalışılmalı.

Ahâlî-yi Hıristiyâniye üzerinde en ziyâde papazların nüfûzu cârî olduğu cihetle ara sıra onlara atiyye ve ikrâmda bulunulmalıdır.

Kasabadaki ulemâdan ba'zılarını vakit vakit kurâ-yı İslâmiyeye göndererek oralarda dolaşdırmalı ve onlar vâsıtasıyla ahâlîyi hükûmete ısındırmalıdır.

İslâm ve Hıristiyânların nâfizü'l-kelam rü'esâsını tanıyıp onlar vâsıtasıyla nüfûz-1 hükûmeti te'sîs ve takviye etmelidir. [s. 18] senede bin liralık kadar zahire alınarak en muhtâc ahâlîye velev az mikdârda olsun tevzî‘ edilmelidir.

\section{"Hülâsâ"}

İşkodra'nın ahvâl ve ihtiyâcâtını ihâtâ ve takdîre ve bunu birkaç sahîfede icmâl ve telhîse aczim mânî‘ olub mücerred telakkî ettiğim emre emsâlen tasvîr-i hâtırâta cür'et eylerim. Ma'rûzât-1 kemterânemin hülâsâsı zîrde ma'râuzdur.

1. İşkodra'ya intihâb ve ta'yîn olunacak her sınıf me'mûrînin muktedir ve tecrübekâr ve hüsn-ü ahlâk ashâbından bulunması ve hüsn-ü idâresi bi’t-tecrübe sâbit olacak me'mûrînin esbâb-1 mucibe-i sahîha olmaksızın oradan kaldırılmaması ve taltîf ve terfî‘leri iktizâ edenlerin yine o havâlî dâhilinde kullanılması.

2. İşkodra'daki kuvve-i askeriyenin bir mertebe-i mükemmeliyet ve kifâyete iblâğ ve göl cihetindeki istihkâmların tesrî‘-i ikmâli tarîk-1 askeriyenin bir an evvel inşâsı.

3. Gölde ve nehirde işletilecek kıt'ada iki üç vapurun mübâya'a ve irsâli

4. İşkodra-Şenkin ve İşkodra-Prizrin yollarıyla kaza ve mevâki'-i askeriyeye ulaşan yolların inşâsı. 
5. İşkodra'dan bed'en ile Puka tarîkiyle Prizrin'e ve Mirdita cihetlerine birer telgraf hattının temdîdi. [s. 19]

6. Mirdita ve Puka kazalarında da a'zâsı yerliden olmak üzere birer mahkeme teşkîli.

7. İşkodra'daki dârü'l-mu'allimînin leylîye kalbî ve leylî i'dâdî mektebinin de yedi sinıfa iblâğ̀.

8. Nefs-i İşkodra ile Zadrime nâhiyesinde birer leylî ibtidâ'î mektebinin te’sîsi.

9. Malisyanın her bayrağında birer mekteb-i ibtidâ'î te'sîsi.

10. Büyük mikyâsda bir sanâyi' mektebinin te’sîs ve inşâs1.

11. İşkodra nâfi'ası için lüzûmı kadar me’mûrîn-i fenniyenin ilâvesi.

12. Boyana göl ve nehriyle Drin ve Kir nehirlerinin tathîr-i mecrâları ve seyr-i sefâ'ine sâlih bir hâle ifrâğı.

13. Gölde ve nehirde isti'mâl edilmek üzere bir tarak vapurunun tedâriki.

14. Jandarmaların yerliden intihâb ve ta'yîni.

15. Sevâhilin mevâki'-i münâsebesinde birer tarassud kal'aları yapılarak telefonla yekdiğerine rabt edilmesi.

16. Seliçe, Tuz kazalarında birer zirâ'at bank şu‘besi teşkîli.

17. Avrupa'dan âlât ve edevât-1 cedide-i zirâ'iye celb olunarak taksit ile ahâlîye verilmesi.

18. Ormanlarının işletilecek bir hâle konulması.

19. Mirdita'nın Oroş ve Fand bayraklarında ve Puka'nın Karacadağ ve Akbale bayraklarında birer nâhiyenin teşkîli.

20. Cibâl dâhilindeki nevâhîye Hıristiyândan birer müdür mu'âvini ta'yîni ve nevâhî mecâlisi a'zâsına yüzer ve kaza a'zâsına ikişer yüz guruş ma'âş verilmesi. [s. 20]

21. İki ya üç-dört seyyâr tabib ta'yîniyle sûret-i dâ'imede kurâ ve cibâlde dolaşdırılması ve hastagânın meccânen tedâvî ettirilerek bu etibbâ vesâtatıyla propagandalar da yapdirılmasi.

22. Mahsûsât-1 mestûre nâmıyla İşkodra’ya hiç olmazsa senevî iki bin lira tahsîsât i‘tâsı. İşkodra Tahrîrât Müdürü Bende Ali Sâ'ib 16 Teşrîn-i Evvel 1327 


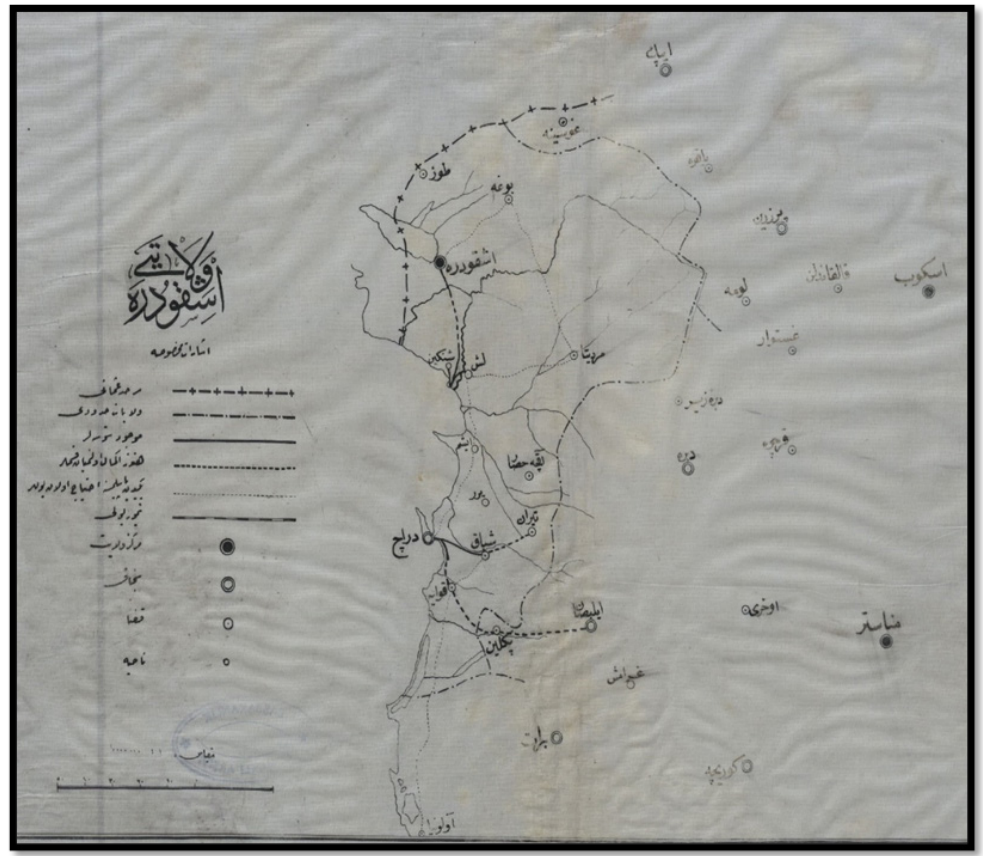

Ek 2: İşkodra Vilayeti haritası ${ }^{67}$

67 BOA.HRT.h.2133. 


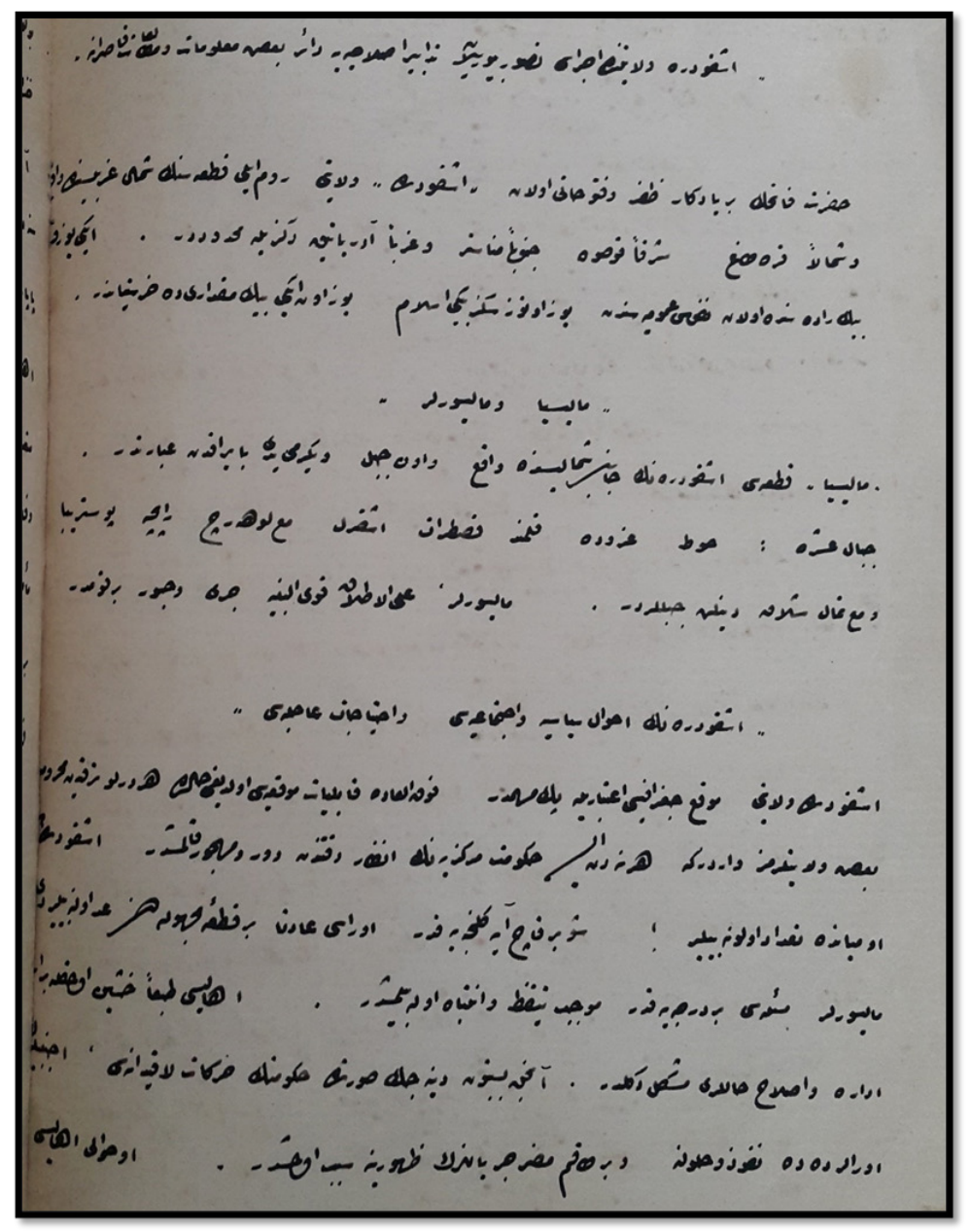

Ek 3: Ali Saib Bey'in layihasının ilk sayfası 


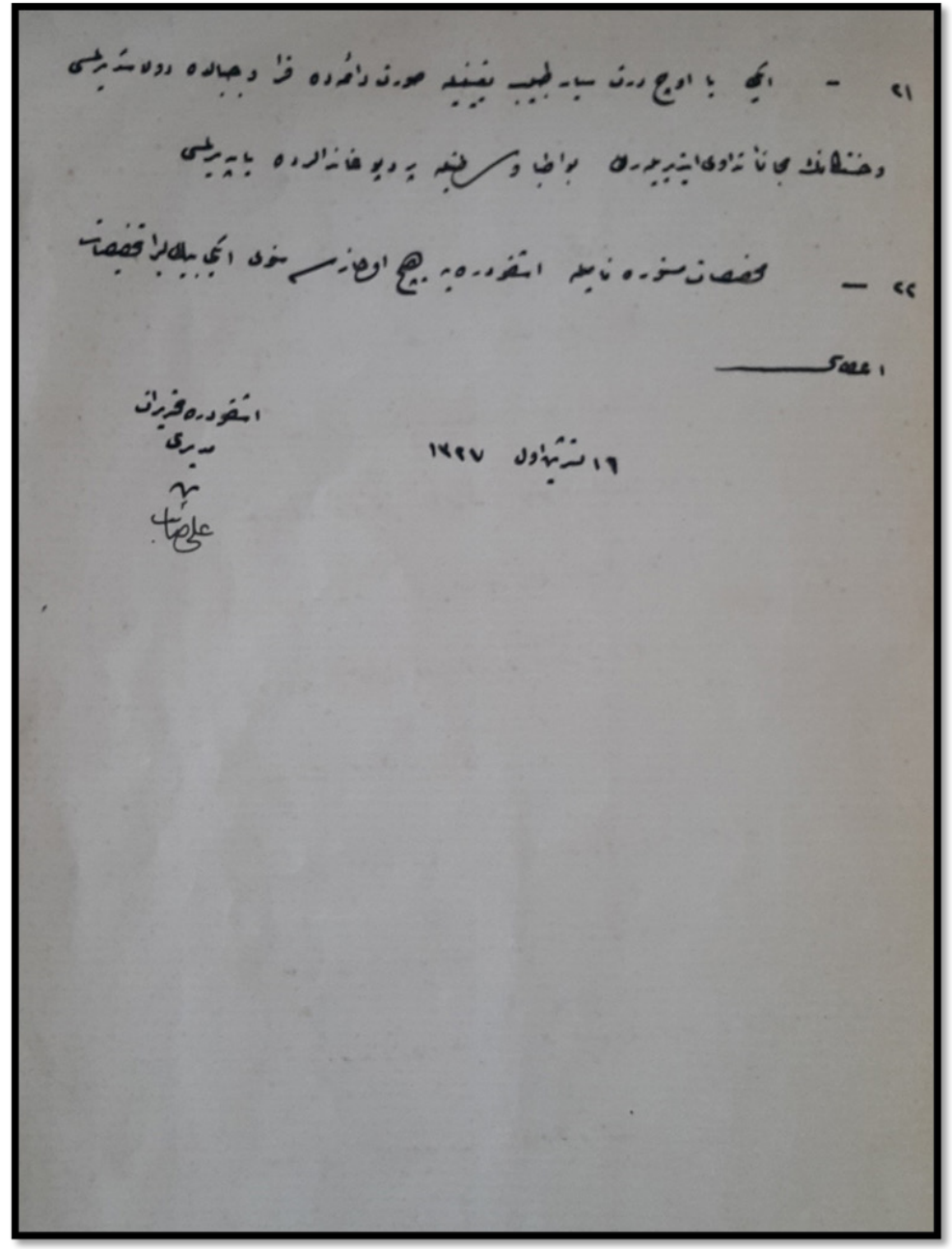

Ek 4: Ali Saib Bey’in layihasının son sayfası 